\title{
Green synthesis and characterization of hexaferrite strontium-perovskite strontium photocatalyst nanocomposites
}

https://doi.org/10.1515/mgmc-2020-0004

Received November 02, 2019; accepted March 07, 2020.

\begin{abstract}
This study presents a preparation of $\mathrm{SrFe}_{12} \mathrm{O}_{19}{ }^{-}$ $\mathrm{SrTiO}_{3}$ nanocomposite synthesis via the green autocombustion method. At first, $\mathrm{SrFe}_{12} \mathrm{O}_{19}$ nanoparticles were synthesized as a core and then, $\mathrm{SrTiO}_{3}$ nanoparticles were prepared as a shell for it to manufacture $\mathrm{SrFe}_{12} \mathrm{O}_{19}-\mathrm{SrTiO}_{3}$ nanocomposite. A novel sol-gel autocombustion green synthesis method has been used with lemon juice as a capping agent. The prepared $\mathrm{SrFe}_{12} \mathrm{O}_{19}-\mathrm{SrTiO}_{3}$ nanocomposites were characterized by using several techniques to characterize their structural, morphological and magnetic properties. The crystal structures of the nanocomposite were investigated via $\mathrm{X}$-ray diffraction (XRD). The morphology of $\mathrm{SrFe}_{12} \mathrm{O}_{19}-$ $\mathrm{SrTiO}_{3}$ nanocomposite was studied by using a scanning electron microscope (SEM). The elemental composition of the materials was analyzed by an energy-dispersive X-ray (EDX). Magnetic properties and hysteresis loop of nanopowder were characterized via vibrating sample magnetometer (VSM) in the room temperature. Fourier transform infrared spectroscopy (FTIR) spectra of the samples showed the molecular bands of nanoparticles. Also, the photocatalytic behavior of nanocomposites has been checked by the degradation of azo dyes under irradiation of ultraviolet light.
\end{abstract}

Keywords: nanocomposite autocombustion; $\mathrm{SrFe}_{12} \mathrm{O}_{19}$; $\mathrm{SrTiO}_{3}$; photocatalysts

\footnotetext{
* Corresponding author: Kambiz Hedayati, Department of Science, Arak University of Technology, Arak, Iran e-mail: k-hedayati@arakut.ac.ir

Zahra Hajian Karahroudi and Mojtaba Goodarzi, Department of Science, Arak University of Technology, Arak, Iran
}

\section{Introduction}

Research for green synthesis about nanomaterials by using natural biomaterials such as plants, flowers, and microorganisms is a new branch of nanotechnology known as green synthesis. Green synthesis of nanoparticles has many benefits such as cost-effectiveness, reduction of pollution as well as being eco-friendly (Zhu et al., 2018; Zinatloo-Ajabshir and Salavati-Niasari, 2015). The $\mathrm{SrFe}_{12} \mathrm{O}_{19}-$ $\mathrm{SrTiO}_{3}$ nanocomposite has been proposed by green synthesis as a novel material. The natural plants that can extract biological capping agents have been green tea (Nadagouda et al., 2010), eucalyptus (Madhavi et al., 2013) and lemon juices. Lemon juice as a rich source of Citric and Ascorbic acid (vitamin C) was used to synthesize nanocomposites and nanoparticles (Ahmadian-Fard-Fini et al., 2020). In this study, the $\mathrm{SrFe}_{12} \mathrm{O}_{19}-\mathrm{SrTiO}_{3}$ nanocomposite was prepared by using lemon juice. The strontium ferrite, have been synthesized by different techniques such as sonochemistry (Palomino et al., 2016), hydrothermal method (Meng et al., 2016; Xia et al., 2013), co-precipitation (Ariaee et al., 2017; Auwal et al., 2016), sol-gel method (Wang et al., 2009a, 2009b) and sol-gel auto-combustion (Almessiere et al., 2018; Yang et al., 2009). Sol-gel auto-combustion method for synthesis of metals and alloys was proposed at a low temperature which is required for reaction, and the combustion does not need any external energy supply (Hua et al., 2011; Mir et al., 2012; Nabiyouni and Ghanbari, 2018; Salavati-Niasari et al., 2010). Traditional reactions for synthesis $\mathrm{SrFe}_{12} \mathrm{O}_{19}$ nanoparticles require a high calcining temperature $\left(1200-1300^{\circ} \mathrm{C}\right)$, though the sol-gel autocombustion method produces homogeneous nanoparticles at much lower calcination temperatures (Jacobo and Bercoff, 2013). The sol-gel auto-combustion synthesis has four steps. Firstly, formation of complexes in the solution, secondly, evaporation the water of the solution and gel formation thirdly, auto-combustion by heated and at the end, obtaining the nanoparticles (Deganello et al., 2009; Mali and Ataie, 2004). 
A type of ferrites is spinel ferrites (Ahmadian-FardFini et al., 2018), like M-type ferrite. M-type ferrite is an attractive magnetic material that has large saturation magnetization and high coercivity (Lahijani et al., 2018). Therefore it can find wide industrial applications in electronic components, magnetic memories, magnets, and sensors (Valenzuela, 2012). The strontium ferrite $\left(\mathrm{SrFe}_{12} \mathrm{O}_{19}\right)$ is an M-type hexagonal ferrite (Hedayati et al., 2016, 2017a; Wohlfarth and Buschow, 1982) with large saturation magnetization and high coercivity. Also, it can be widely used for electronic components, high-density recording media, magnets, sensors, and microwave devices (Fang et al., 2000; Garcia-Cerda et al., 2004).

The dielectric properties of strontium ferrite could be improved via the concatenation of perovskite strontium $\left(\mathrm{SrTiO}_{3}\right)$. Perovskite-type has a general formula as $\mathrm{ABO}_{3}$. The $A$ is a trivalent rare-earth and $B$ is a $3 d$ transition metal (Eskandari et al., 2019; Salavati-Niasari and Davar, 2006). Perovskites are usually used in environmentally friendly catalytic systems (Thornton et al., 1982). In this research, perovskite strontium has been synthesized using the sol-gel auto-combustion method.

In recent years, heterogeneous photocatalysis was developed as several forms, photodegradation of organizational pollutant have been recently the most investigated. $\mathrm{SrTiO}_{3}$ is cost-effective and its inert photostability compared to other semiconductor photocatalysts was considered higher than photocatalysts effect of other semiconductor (Gaya and Abdullah, 2008).

The present paper seeks to offer a viable heterogeneous photocatalytic degradation alternative for the degradation of organic pollutions in wastewater by using $\mathrm{SrFe}_{12} \mathrm{O}_{19}-\mathrm{SrTiO}_{3}$ nanocomposite. To acquire the desired photodegradation efficiency, combining diverse techniques and approaches might be essential. In this regard, adding magnetic properties needs to be established because by applying an external magnetic field, nanoparticles can be controlled and separated from the solution (Dong et al., 2015). The nanocomposite of $\mathrm{SrFe}_{12} \mathrm{O}_{19}-\mathrm{SrTiO}_{3}$ has been synthesized using combustion methodologies. It is thus worth carrying out a study of synthesizing the products of $\mathrm{SrFe}_{12} \mathrm{O}_{19}$ with doping $\mathrm{SrTiO}_{3}$.

\section{Experimental}

\subsection{Materials}

All the chemical materials that have been used in this experiment, have a very high purity and have been produced by Merck company, included iron nitrate monohydrate $\left(\mathrm{Fe}\left(\mathrm{NO}_{3}\right)_{3} \cdot 9 \mathrm{H}_{2} \mathrm{O}\right)$, strontium nitrate $\left(\mathrm{Sr}\left(\mathrm{NO}_{3}\right)_{2}\right)$ (Garcia-Cerda et al., 2004; SalavatiNiasari, 2004), ammonia $\left(\mathrm{NH}_{3}\right)$ (Auwal et al., 2016; Salavati-Niasari, 2005a; Salavati-Niasari and Amiri, 2005), citric acid $\left(\mathrm{C}_{6} \mathrm{H}_{8} \mathrm{O}_{7}\right)$ (Deganello et al., 2009), titanium isopropoxide $\left(\mathrm{C}_{12} \mathrm{H}_{28} \mathrm{O}\right.$ Ti $)$, ethanol $\left(\mathrm{C}_{2} \mathrm{H}_{5} \mathrm{OH}\right)$, and other chemicals materials were used without further purification. In order to synthesize $\mathrm{SrFe}_{12} \mathrm{O}_{19}$ nanoparticles, deionized and distilled water used. The sample was prepared via green synthesis using juice of fresh lemon. Pieces of fresh lemon in lemon juice were washed and squeezed, and then the lemon juice was filtered.

\subsection{Preparation of $\mathrm{SrFe}_{12} \mathrm{O}_{19}$ nanoparticles}

$\mathrm{SrFe}_{12} \mathrm{O}_{19}$ nanoparticle was prepared by green synthesis using the sol-gel auto combustion method. First, $100 \mathrm{~mL}$ of lemon juice was heated at $50-100^{\circ} \mathrm{C}$ for $15 \mathrm{~min}$ and then solution was filtered to get the lemon extract. The starting reagents that used were stoichiometric amounts of $2.3 \mathrm{~g}$ of $\mathrm{Fe}\left(\mathrm{NO}_{3}\right)_{3} \cdot 9 \mathrm{H}_{2} \mathrm{O}$ and $0.2 \mathrm{~g} \mathrm{Sr}\left(\mathrm{NO}_{3}\right)_{2}$ (molar ratio of $\mathrm{Fe} / \mathrm{Sr}: 12 / 2$ ) were separately dissolved in $20 \mathrm{~mL}$ of deionized water at room temperature to form a clear hydrous solution (Garcia-Cerda et al., 2004; Mohandes et al., 2010, 2014; Shabanian et al., 2014). The two above mentioned solutions were mixed together and then continuously were stirred using a magnetic stirrer. After $15 \mathrm{~min}, 15 \mathrm{~mL}$ lemon juice extract was added to the mixture (Almessiere et al., 2018). After stirring for $20 \mathrm{~min}, 5 \mathrm{~mL} \mathrm{NH}_{3}$ was added drop wise in the pioneer solution until it became neutral ( $\mathrm{pH} 7$ ), as the solution was getting more and more viscous during heating until the water vaporized (Ariaee et al., 2017; Yousefi et al., 2011). The temperature was gradually increased to $150^{\circ} \mathrm{C}$ to remove the water remnant and a brownish solution was formed. Condensation reaction occurs between adjoining metal nitrates and citric acid. Its conclusion continued until the resulting solution known as a sol. The resultant sol on the hot heated stirrer was heated at $50-100^{\circ} \mathrm{C}$ under constant stirring until the water of solution was evaporated making a viscous liquid called gel. Then, the gel auto-ignited suddenly and finally evaporated releasing black ash and the exhaust of $\mathrm{CO}_{2}$, $\mathrm{N}_{2}$, and $\mathrm{H}_{2} \mathrm{O}$ gases. The $\mathrm{SrFe}_{12} \mathrm{O}_{19}$ powder was washed with deionized water and then the collected powder was dried in the oven at $80^{\circ} \mathrm{C}$ for $48 \mathrm{~h}$. The resulting nanoparticles were calcined at $850^{\circ} \mathrm{C}$ for 120 min to obtain single-phase $\mathrm{SrFe}_{12} \mathrm{O}_{19}$. 


\subsection{Preparation of $\mathrm{SrTiO}_{3}$ nanoparticles}

In order to fabricate nanocrystals of perovskite strontium by auto-combustion sol-gel, $0.22 \mathrm{~g}$ of $\mathrm{Sr}\left(\mathrm{NO}_{3}\right)_{2}$ was slowly dissolved in $50 \mathrm{~mL}$ of ethanol by a magnetic stirrer. In the next step, $0.3 \mathrm{~g}$ of $\mathrm{C}_{12} \mathrm{H}_{28} \mathrm{O}_{4}$ Ti added to the above solution. After $10 \mathrm{~min}, 5 \mathrm{~mL}$ of lemon juice was added to the solution at room temperature as a gel agent. A quantity of $5 \mathrm{~mL}$ of $\mathrm{NH}_{3}$ as a $\mathrm{pH}$ adjuster in 7 was added to the solution. The solution was heated until applied after self-ignition flaring and burning smoke occurs. Then the gray powder was obtained by the self-combustion sol-gel process. The resulting product was rinsed by deionized water and then centrifuged. The nanoparticles dried in an oven at $80^{\circ} \mathrm{C}$ for one day, and finally, the resulting powder was calcified at $500^{\circ} \mathrm{C}$ for $2 \mathrm{~h}$ inside the oven.

\subsection{Synthesis of $\mathrm{SrFe}_{12} \mathrm{O}_{19}-\mathrm{SrTiO}_{3}$ nanocom- posites $(50 / 50 \% \mathrm{w} / \mathrm{w})$}

At first for the production of hexaferrite strontiumperovskite strontium nanocomposite, $0.1 \mathrm{~g} \mathrm{SrFe}_{12} \mathrm{O}_{19}$ nanoparticles that were synthesized by using the autocombustion method was dissolved in $100 \mathrm{~mL}$ of ethanol at room temperature. Then, $0.1 \mathrm{~g}$ of $\operatorname{Sr}\left(\mathrm{NO}_{3}\right)_{2}$ and $0.1 \mathrm{~g}$ $\mathrm{C}_{12} \mathrm{H}_{28} \mathrm{O}_{4}$ Ti were dissolved by a mechanical stirrer on the styrene at room temperature for $3 \mathrm{~h}$. Then the solution was continuously stirred using a mechanical stirrer for getting a better homogeneity for $3 \mathrm{~h} .15 \mathrm{~mL}$ of lemon juice was added to the solution as a capping agent. After stirring for $20 \mathrm{~min}$, the $\mathrm{pH}$ value of the solution was adjusted to 7 with adding $7 \mathrm{~mL}$ ammonia solution. The green solution was evaporated slowly at $80^{\circ} \mathrm{C}$ until a little of sol remained as the solution was getting vicious and remained water vaporization. The temperature was increased to $150^{\circ} \mathrm{C}$ until starting the auto-combustion. The product powder was obtained by filtering and washing the suspension with deionized water. The obtained black powder contained $\mathrm{SrTiO}_{3}-\mathrm{SrFe}_{12} \mathrm{O}_{19}$ (with weight ratio 1:1) and the nanocomposite placed in a dryer oven in order to dry at $80^{\circ} \mathrm{C}$ for $48 \mathrm{~h}$. Figure 1 shows the schematic for the experimental setup for nanoparticle and nanocomposite preparation.

\section{Characterization}

X-ray diffraction patterns were recorded by using a Philips (Amsterdam, Netherlands) X-ray diffractometer using $\mathrm{CuK} \alpha$ radiation $(\lambda=1.54 \AA$ ). SEM images and EDX elemental analysis were obtained by using a LEO (Cambridge, UK) instrument (Model 1455VP). Vibration Sampling Magnetometer was used to investigate the magnetic properties and hysteresis loop of synthesized materials. The magnetic measurements were carried out at room temperature using a VSM (MeghnatisKavir Kashan

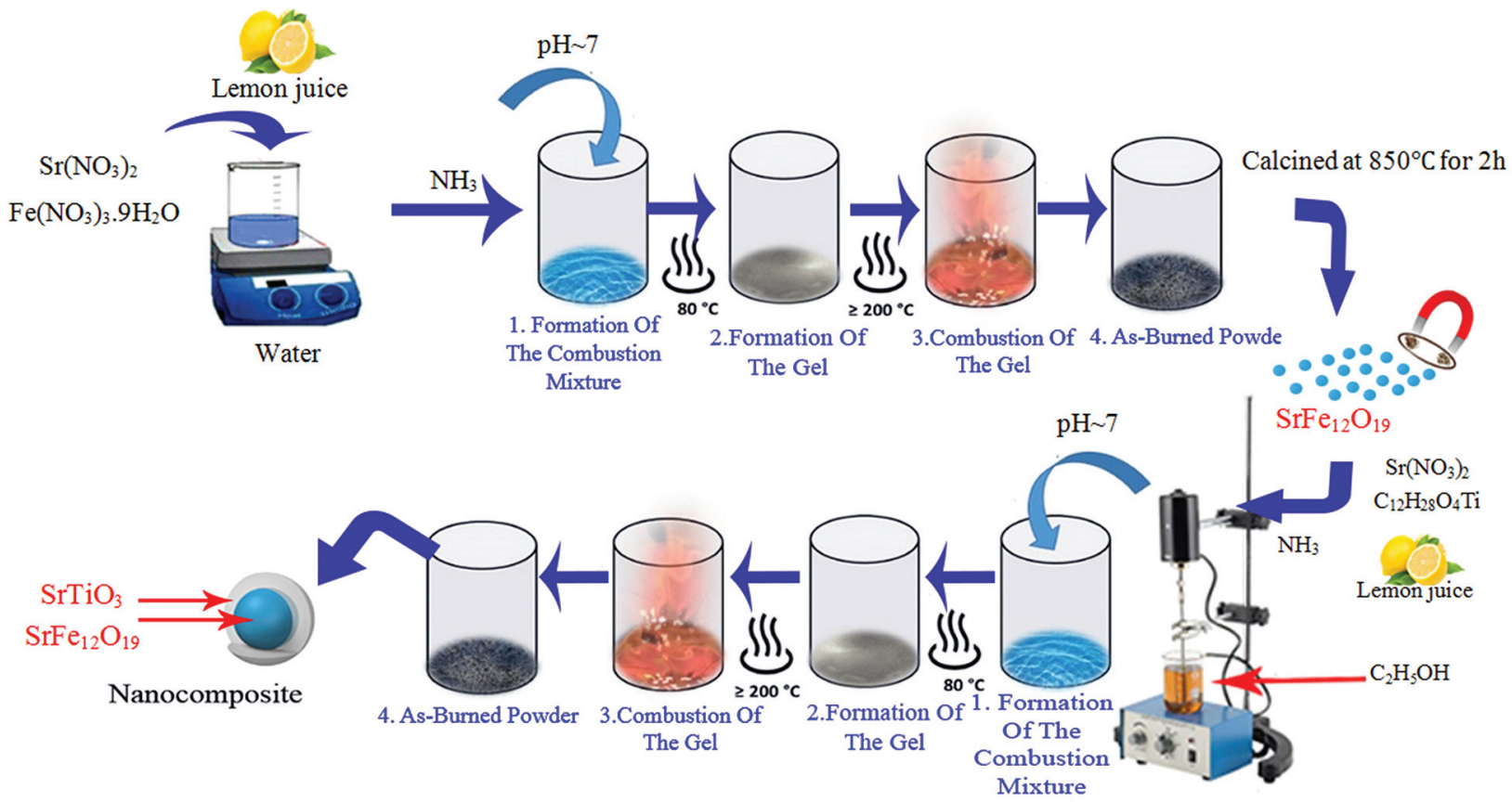

Figure 1: Schematic of nanoparticle $\mathrm{SrFe}_{12} \mathrm{O}_{19}$ and nanocomposite $\mathrm{SrFe}_{12} \mathrm{O}_{19}-\mathrm{SrTiO}_{3}$ preparation. 
Company, Iran) in an applied magnetic field sweeping between \pm 10000 Oe. To identify chemical bonds between the atoms the FTIR by Thermal camera BRUKER model ALPHA (Germany) instrument using KBr pellets was used. The optical properties of the particles from the UV-Vis Shimadzu UV-2600m (China) have been used.

\section{Results and discussion}

\subsection{XRD analysis}

The crystalline structure and compound formation of prepared and post sintered samples were studied using $\mathrm{X}$-Ray diffraction in the $2 \theta$ range $10-80^{\circ}$ with step size $0.02^{\circ}$ at room temperature (Salavati-Niasari, 2006; SalavatiNiasari and Davar, 2006).

The average crystallite size of the nanocrystals was calculated by Debye-Scherrer formula (Khorsand Zak et al., 2011; Salavati-Niasari, 2006):

$$
D=\frac{k \lambda}{\beta \cos \theta}
$$

where $D$ is mean crystallite size, $\theta$ is the Bragg diffraction angle and $\beta$ is the width of the observed diffraction peak at its half maximum intensity (FWHM), $k$ is the shape factor (about 0.9$)$, and $\lambda$ is the X-ray wavelength $(0.154 \mathrm{~nm})$ (Khorsand Zak et al., 2011).
The broadening of peaks may be related to strain due to crystal imperfections and distortion. Using the Williamson-Hall method, it is assumed that size and strain broadening are additive components of the total integral breadth of a Bragg peak (Hedayati et al., 2017b; Mousavi-Kamazani et al., 2016; Safardoust-Hojaghan and Salavati-Niasari, 2017). The Williamson-Hall formula is expressed in Eq. 2:

$$
\beta \cos \theta=\frac{k \lambda}{D}+4 \varepsilon \sin \theta
$$

where $\varepsilon$ is a strain of crystal lattice. With the drawing of the $\beta \cos \theta$ diagram in terms of $\sin \theta$ the optimum line equation can find the size of the crystallite and the network strain.

The XRD pattern of the $\mathrm{SrFe}_{12} \mathrm{O}_{19}$ nanoparticles calcinationsat $850^{\circ} \mathrm{C}$ was investigated in Figure 2. The XRD pattern of $\mathrm{SrFe}_{12} \mathrm{O}_{19}$ has shown a pattern of pure hexagonal phase (JCPDS No. 24-1207) with P63/mmc space group that is pure hexaferrite strontium nanoparticles. The mean value of the nano-crystalline of $\mathrm{SrFe}_{12} \mathrm{O}_{19}$ was calculated to be $56 \mathrm{~nm}$ using the Debye-Scherrer's formula and $55 \mathrm{~nm}$ by the Williamson-Hall method. Also, the strain of the network was equal to 0.000175 .

The X-ray diffraction of the $\mathrm{SrTiO}_{3}$ nanoparticle which calcinated at $500^{\circ} \mathrm{C}$, was determined and shown in Figure 3. This shows the cubic phase (JCPDS No. 05-0634) with the Pm3m space group was prepared which is consistent with pure perovskite strontium. The mean value of the nano-crystalline size of $\mathrm{SrTiO}_{3}$

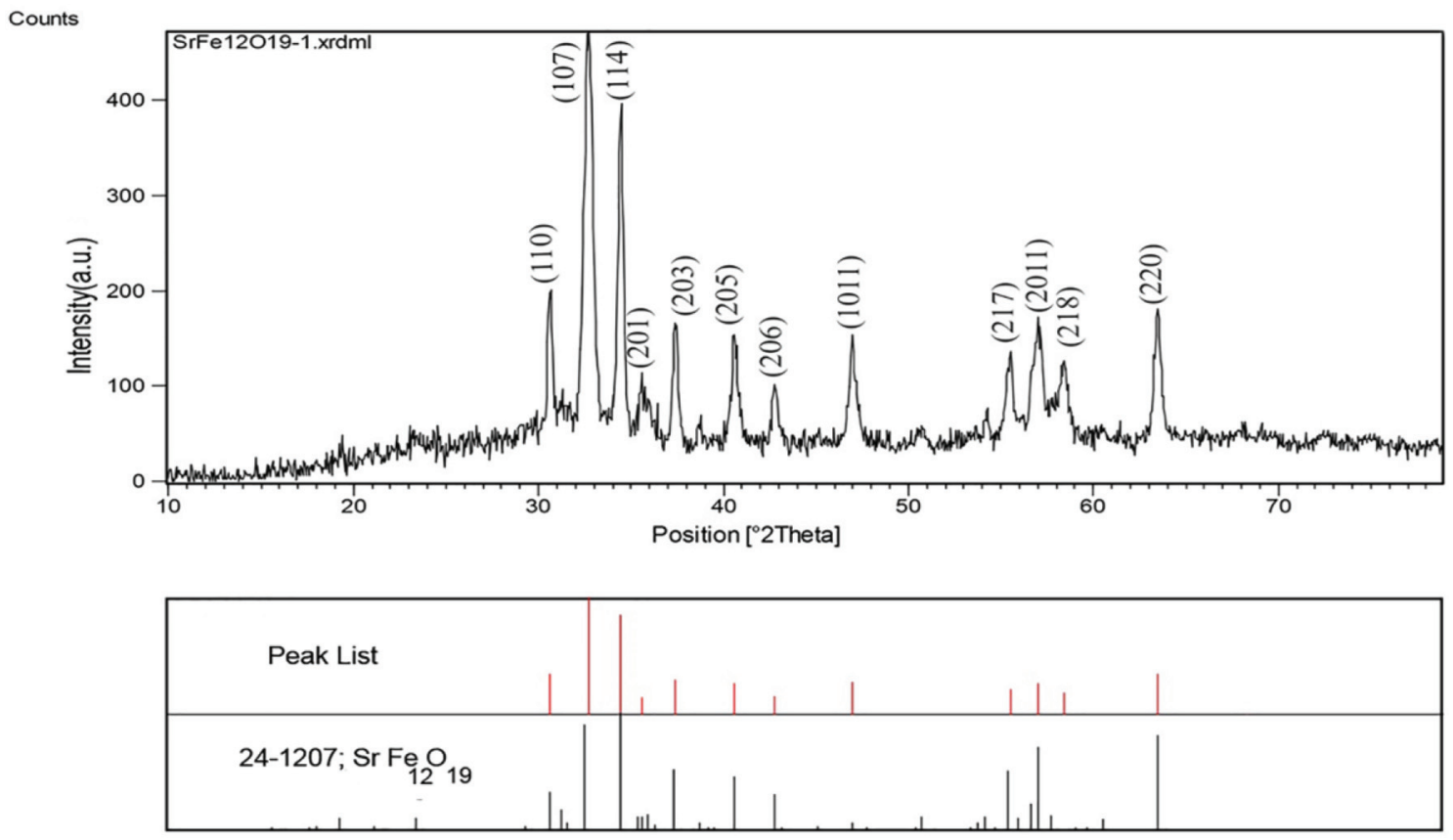

Figure 2: XRD pattern of the $\mathrm{SrFe}_{12} \mathrm{O}_{19}$ samples prepared at calcination temperature of $850^{\circ} \mathrm{C}$. 

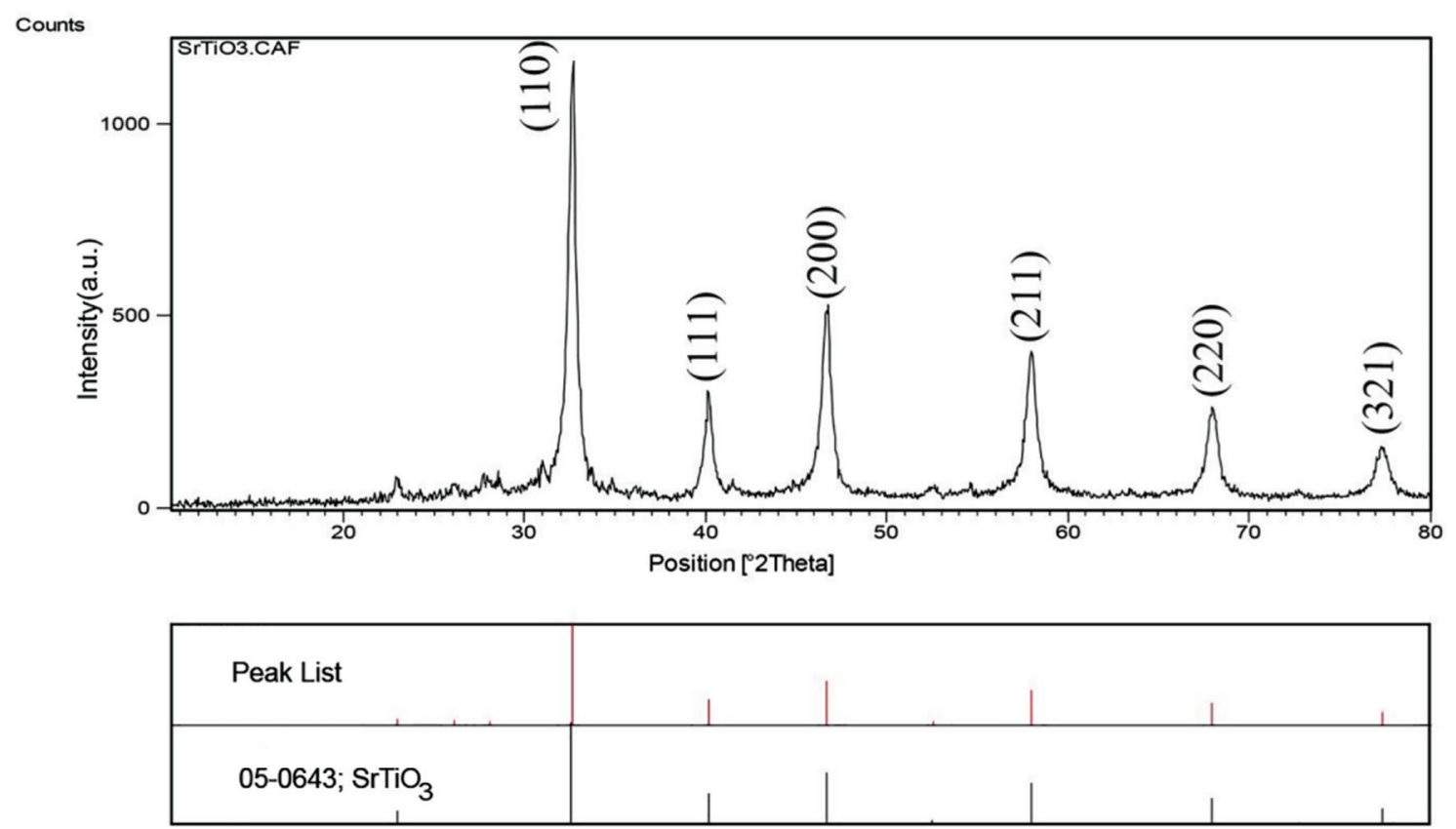

Figure 3: XRD spectrum of $\mathrm{SrTiO}_{3}$ nanoparticle that calcinate at $500^{\circ} \mathrm{C}$.

was calculated to be $40 \mathrm{~nm}$ using the Debye-Scherrer's formula, $49 \mathrm{~nm}$ by the Williamson-Hall's formula and the strain of the grid was 0.00075 .

The XRD of the composition of the $\mathrm{SrFe}_{12} \mathrm{O}_{19}-\mathrm{SrTiO}_{3}$ nanocomposite was also investigated. Figure 4 confirms the presence of both $\mathrm{SrFe}_{12} \mathrm{O}_{19}$ and pure perovskite strontium phase. The average crystalline size for $\mathrm{SrFe}_{12} \mathrm{O}_{19}$, $\mathrm{SrTiO}_{3}$ nanoparticles, $\mathrm{SrFe}_{12} \mathrm{O}_{19}-\mathrm{SrTiO}_{3}$ nanocomposite, and $\varepsilon$ were calculated via Debye-Scherrer's formula and Williamson-Hall method and are shown in Table 1.

\subsection{FTIR analysis}

Figure 5 shows the FTIR spectrum of $\mathrm{SrFe}_{12} \mathrm{O}_{19}$ nanoparticles that calcinated at $850^{\circ} \mathrm{C}$ in the range of 400 to $4000 \mathrm{~cm}^{-1}$. The peak near $3420 \mathrm{~cm}^{-1}$ is due to the stretching modes of the $\mathrm{O}-\mathrm{H}$ band of the free or adsorbed water (Davar et al., 2010; Salavati-Niasari et al., 2005b). The weak band near $1632 \mathrm{~cm}^{-1}$ is attributed to the $\mathrm{H}-\mathrm{O}-\mathrm{H}$ bending vibration mode. The Peak corresponding to the $\mathrm{Fe}-\mathrm{O}$ was observed at $593 \mathrm{~cm}^{-1}$ and the peak in $435 \mathrm{~cm}^{-1}$ is indicative of $\mathrm{Sr}-\mathrm{O}$.

The FTIR spectrum of $\mathrm{SrTiO}_{3}$ nanoparticles that calcinated at $500^{\circ} \mathrm{C}$ is shown in Figure 6 . The band at $566 \mathrm{~cm}^{-1}$ was assigned to Ti-O stretching vibration mode and peak in $439 \mathrm{~cm}^{-1}$ indicates $\mathrm{Sr}-\mathrm{O}$. The broadband at $3384 \mathrm{~cm}^{-1}$ was assigned to the $\mathrm{O}-\mathrm{H}$ stretching vibration and the weak band near $1629 \mathrm{~cm}^{-1}$ was assigned to vibration mode of $\mathrm{H}-\mathrm{O}-\mathrm{H}$ bending.
FTIR spectrum of the $\mathrm{SrFe}_{12} \mathrm{O}_{19}-\mathrm{SrTiO}_{3}$ nanocomposite is shown in Figure 7. The spectrum shows bands near $3269 \mathrm{~cm}^{-1}$ which are attributed to the stretching modes and $\mathrm{O}-\mathrm{H}$ bending vibrations of water. In addition, absorption peaks near $1393 \mathrm{~cm}^{-1}$ and $1356 \mathrm{~cm}^{-1}$ refer to Ti-O-Ti vibrations. The main Absorption peaks in $434 \mathrm{~cm}^{-1}$ and $550 \mathrm{~cm}^{-1}$ appertain to the $\mathrm{Fe}-\mathrm{O}$ bands in $\mathrm{SrFe}_{12} \mathrm{O}_{19}$ and the peak of $591 \mathrm{~cm}^{-1}$ belongs to $\mathrm{Ti}-\mathrm{O}$ in $\mathrm{SrTiO}_{3}$. The absorption peak at $759 \mathrm{~cm}^{-1}$ belongs to the Ti-O-Sr vibrations in the $\mathrm{SrTiO}_{3}$. The peak at $1709 \mathrm{~cm}^{-1}$ is the $\mathrm{C}-0$ and at $1626 \mathrm{~cm}^{-1}$ is tensile transplants $\mathrm{H}-\mathrm{O}-\mathrm{H}$. The absorption peak at $1393 \mathrm{~cm}^{-1}$ is $\mathrm{C}=\mathrm{O}$ and at $1186 \mathrm{~cm}^{-1}$ for the $\mathrm{N}-\mathrm{H}$ bond, which, if calcined, disappear in the absorption spectrum.

\subsection{Morphological analysis}

Figure 8 shows the SEM image of $\mathrm{SrFe}_{12} \mathrm{O}_{19}$ nanoparticles that synthesized auto-combustion with fresh lemon without calcination. Figure 9 shows the same material with calcinated temperature $850^{\circ} \mathrm{C}$ for $2 \mathrm{~h}$. According to SEM images, the $\mathrm{SrFe}_{12} \mathrm{O}_{19}$ nanoparticles without calcination are agglomerated but when nanoparticles calcinated at $850^{\circ} \mathrm{C}$, the particle exhibited needle shape with the average particle size around $40 \mathrm{~nm}$. Figure 10 shows SEM images of the $\mathrm{SrTiO}_{3}$ nanoparticle synthesis auto-combustion without calcination and Figure 11 shows SEM of $\mathrm{SrTiO}_{3}$ nanoparticle with calcinated temperature of $500^{\circ} \mathrm{C}$. SEM images of the nanoparticles without 


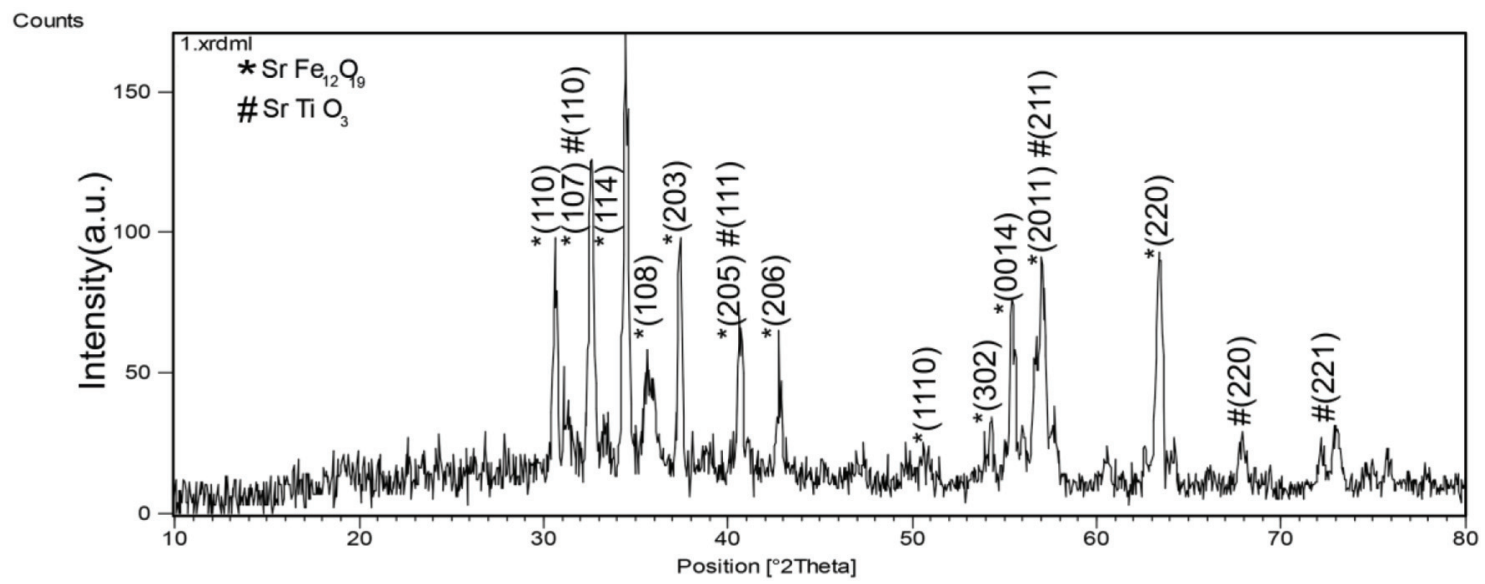

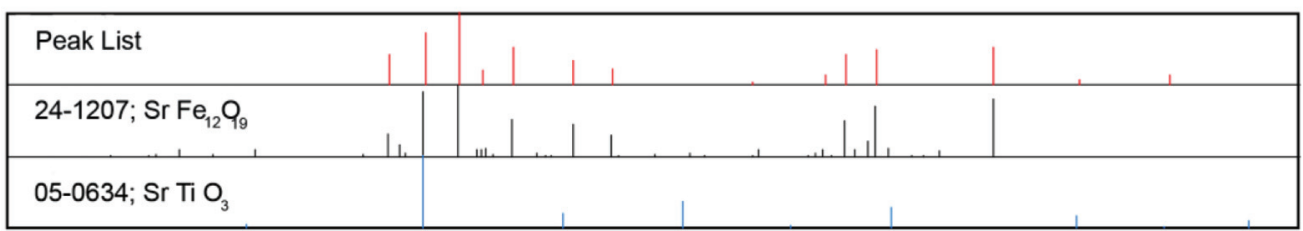

Figure 4: XRD patterns of $\mathrm{SrFe}_{12} \mathrm{O}_{19}-\mathrm{SrTiO}_{3}$ nanocomposite.

Table 1: Crystaline size for XRD paterns.

\begin{tabular}{lccc}
\hline & D. Scherrer $(\mathrm{nm})$ & D. Williamson-Hall $(\mathrm{nm})$ & $\boldsymbol{\varepsilon}$ strain \\
\hline $\mathrm{SrFe}_{12} \mathrm{O}_{19}$ calcination at $850^{\circ} \mathrm{C}$ & 56 & 55 & 0.000175 \\
$\mathrm{SrTiO}_{3}$ calcination at $500^{\circ} \mathrm{C}$ & 40 & 49 & 0.00075 \\
$\mathrm{SrFe}_{12} \mathrm{O}_{19}-\mathrm{SrTiO}_{3}$ & 54 & 59 & 0.00055 \\
\hline
\end{tabular}

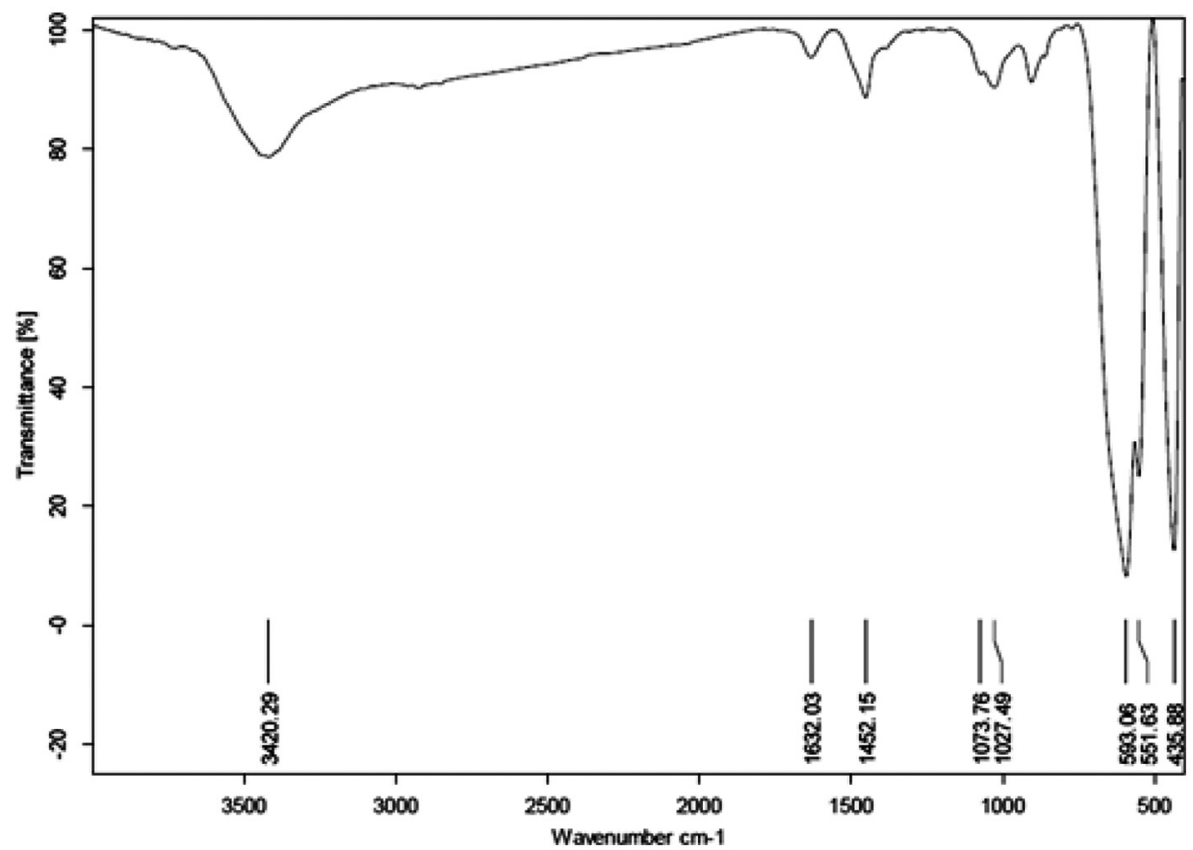

Figure 5: FT-IR spectrum of $\mathrm{SrFe}_{12} \mathrm{O}_{19}$ calcinated at $850^{\circ} \mathrm{C}$. 


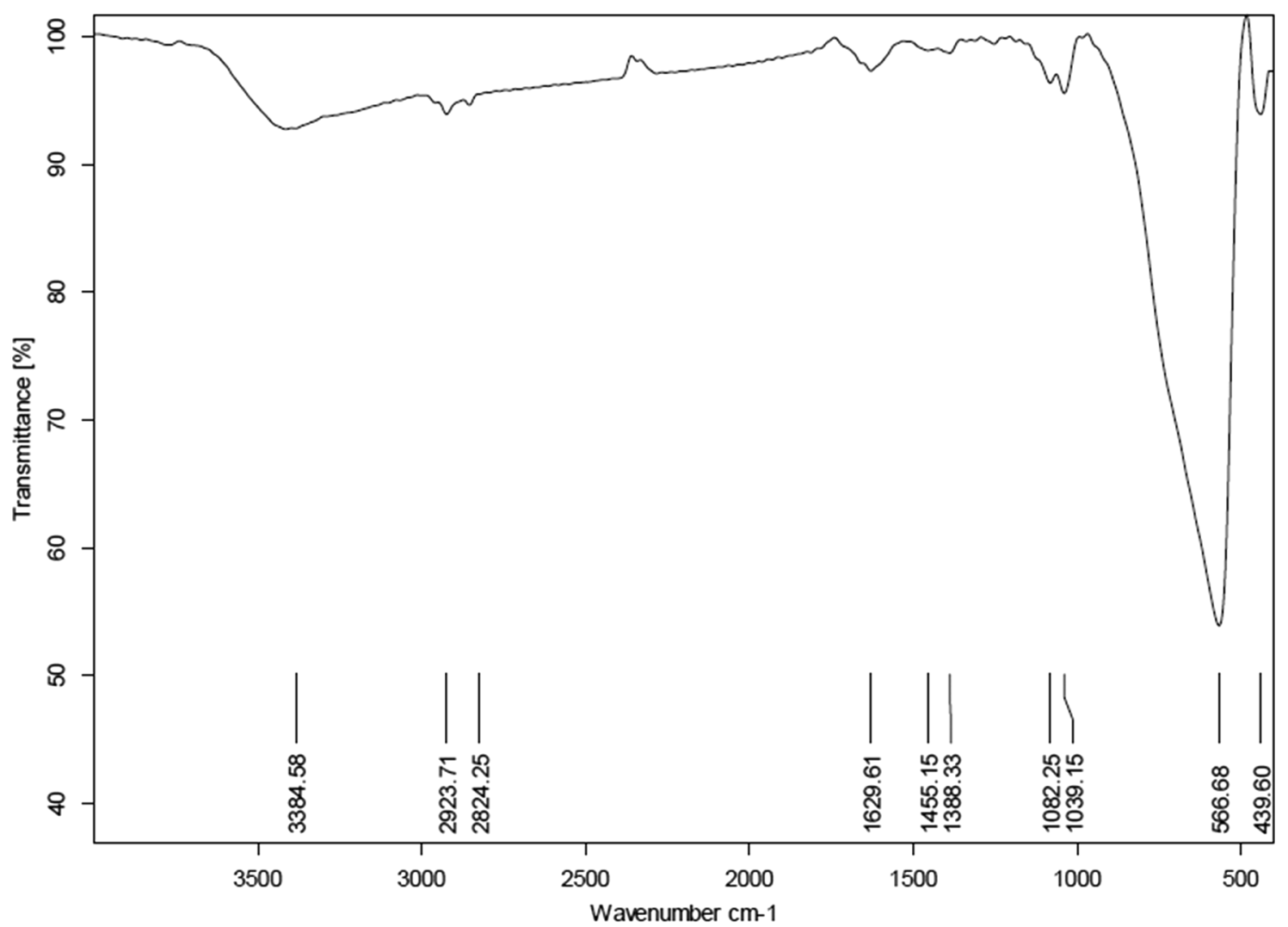

Figure 6: FT-IR spectrum of $\mathrm{SrTiO}_{3}$ calcinated at $500^{\circ} \mathrm{C}$.

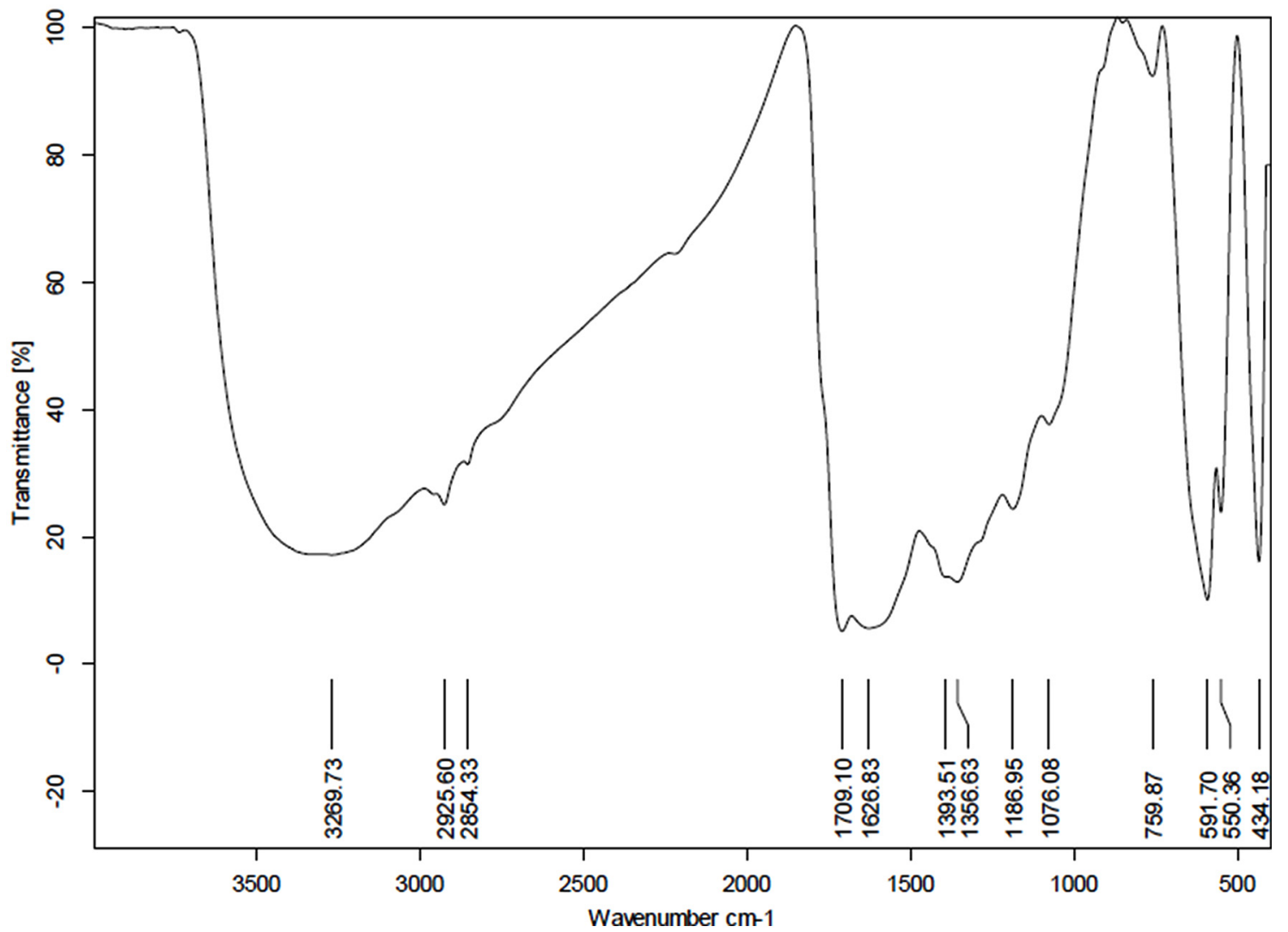

Figure 7: FT-IR spectrum of nanocomposite $\mathrm{SrFe}_{12} \mathrm{O}_{19}-\mathrm{SrTiO}_{3}$. 


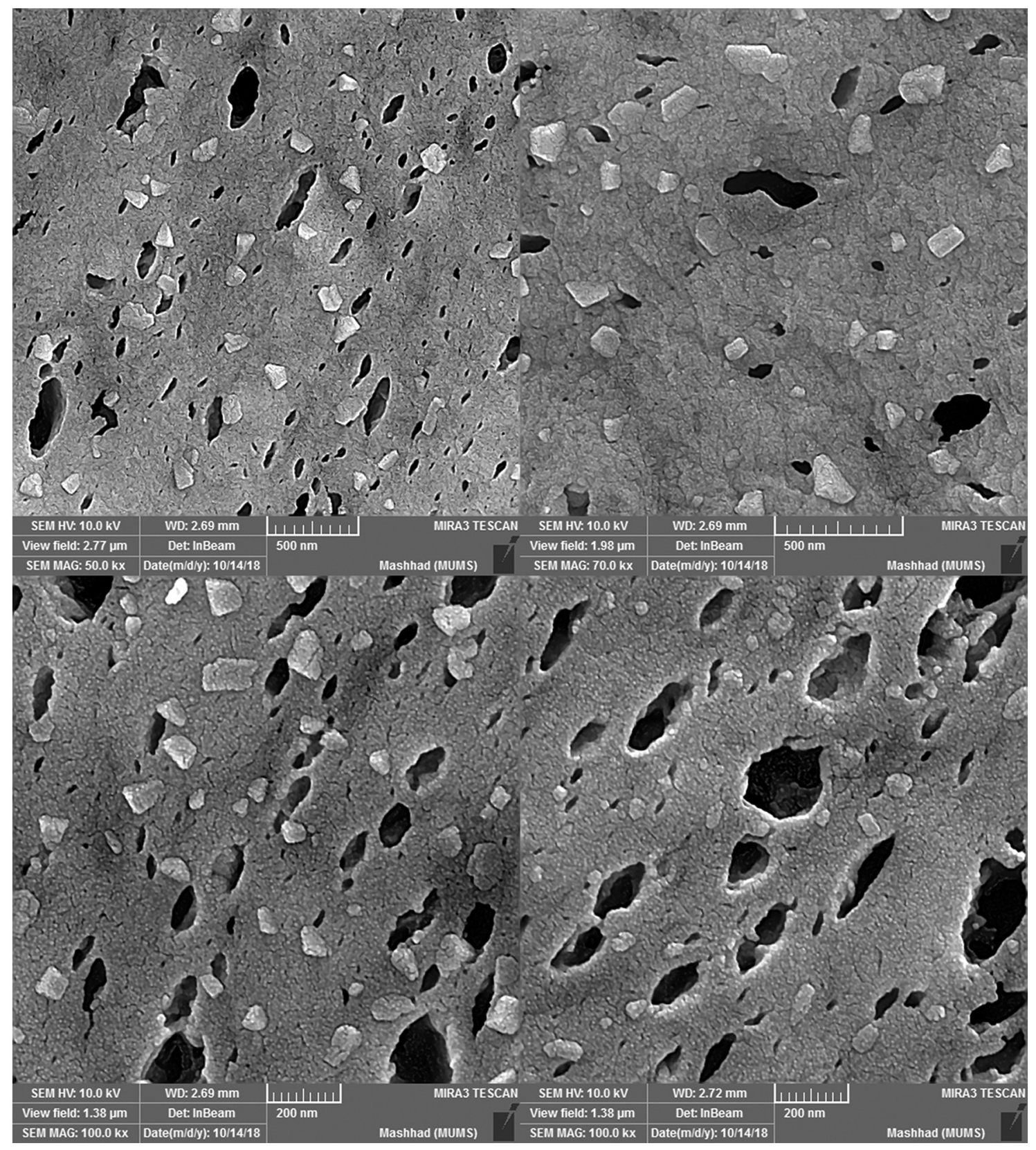

Figure 8: $\mathrm{SEM}$ images of $\mathrm{SrFe}_{12} \mathrm{O}_{19}$ nanoparticle synthesis auto-combustion.

calcination are agglomerated but when nanoparticles calcinated at $500^{\circ} \mathrm{C}$, they found Spherical shape with the average particle size around $35 \mathrm{~nm}$. Figure 12 illustrates SEM images of the synthesized $\mathrm{SrFe}_{12} \mathrm{O}_{19}-\mathrm{SrTiO}_{3}$ nanocomposite. The particles have needle and plane shapes.

\subsection{EDX analysis}

The EDX analysis of $\mathrm{SrFe}_{12} \mathrm{O}_{19}$ nanoparticles has been shown in Figure 13. The EDX of $\mathrm{SrTiO}_{3}$ nanoparticle and $\mathrm{SrFe}_{12} \mathrm{O}_{19}-\mathrm{SrTiO}_{3}$ nanocomposite is indicated in Figures 14 and 15, respectively. The spectra have verified particles without impurities and a good estimate with stoichiometric amounts of elements in nanoparticles.

\subsection{Magnetic properties}

Magnetic properties of magnetic materials such as saturation magnetization $\left(M_{s}\right)$, remanence magnetization $\left(\mathrm{M}_{\mathrm{r}}\right)$ and coercivity $\left(\mathrm{H}_{\mathrm{c}}\right)$ are determined by the hysteresis loop. The room temperature hysteresis loop of $\mathrm{SrFe}_{12} \mathrm{O}_{19}$ 


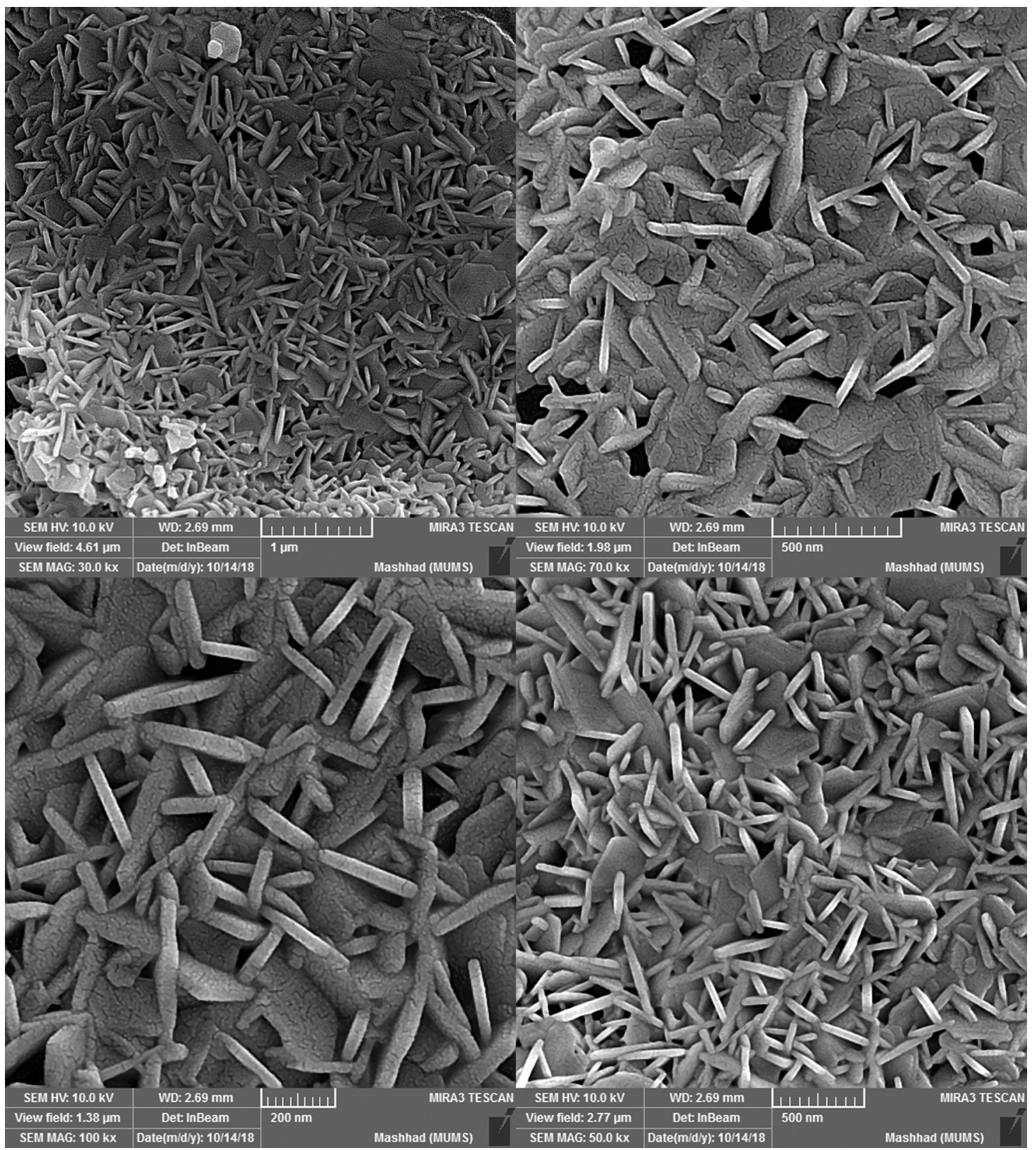

Figure 9: $\mathrm{SEM}$ images of $\mathrm{SrFe}_{12} \mathrm{O}_{19}$ nanoparticle synthesis autocombustion that calcinate at $850^{\circ} \mathrm{C}$.

was studied via vibration VSM instrument that was shown in Figure 16. The result indicates that the sample exhibit superparamagnetic property. The saturation magnetization of $\mathrm{SrFe}_{12} \mathrm{O}_{19}$ nanoparticles is $13 \mathrm{emu} / \mathrm{g}$. The hysteresis loop of $\mathrm{SrFe}_{12} \mathrm{O}_{19}$ nanoparticles calcined at $850^{\circ} \mathrm{C}$ is shown in Figure 17. Saturation magnetization around $54 \mathrm{emu} / \mathrm{g}$, remanence magnetization $30 \mathrm{emu} /$ gand, and coercivity about 5000 Oe have been achieved. These amounts were confirmed as calcination of both magnetization and coercivity were increased as shown in the hysteresis loop of a ferromagnetic after calcination.
Figure 18 shows the magnetic property of the $\mathrm{SrFe}_{12} \mathrm{O}_{19}-$ $\mathrm{SrTiO}_{3}$ nanocomposite. Saturation magnetization, remanence magnetization and coercivity about $20 \mathrm{emu} / \mathrm{g}$, $12 \mathrm{emu} / \mathrm{g}$ and 4500 Oe were obtained respectively. The magnetic properties of the $\mathrm{SrFe}_{12} \mathrm{O}_{19}-\mathrm{SrTiO}_{3}$ nanocomposites were affected by the magnetic exchange interactions between the different phases of these nanocomponents. It is clear that the nanocomposite is classified as a hard magnetic material. The magnetization and coercivity are decreased in the composite because of the $\mathrm{SrTiO}_{3}$ phase. 


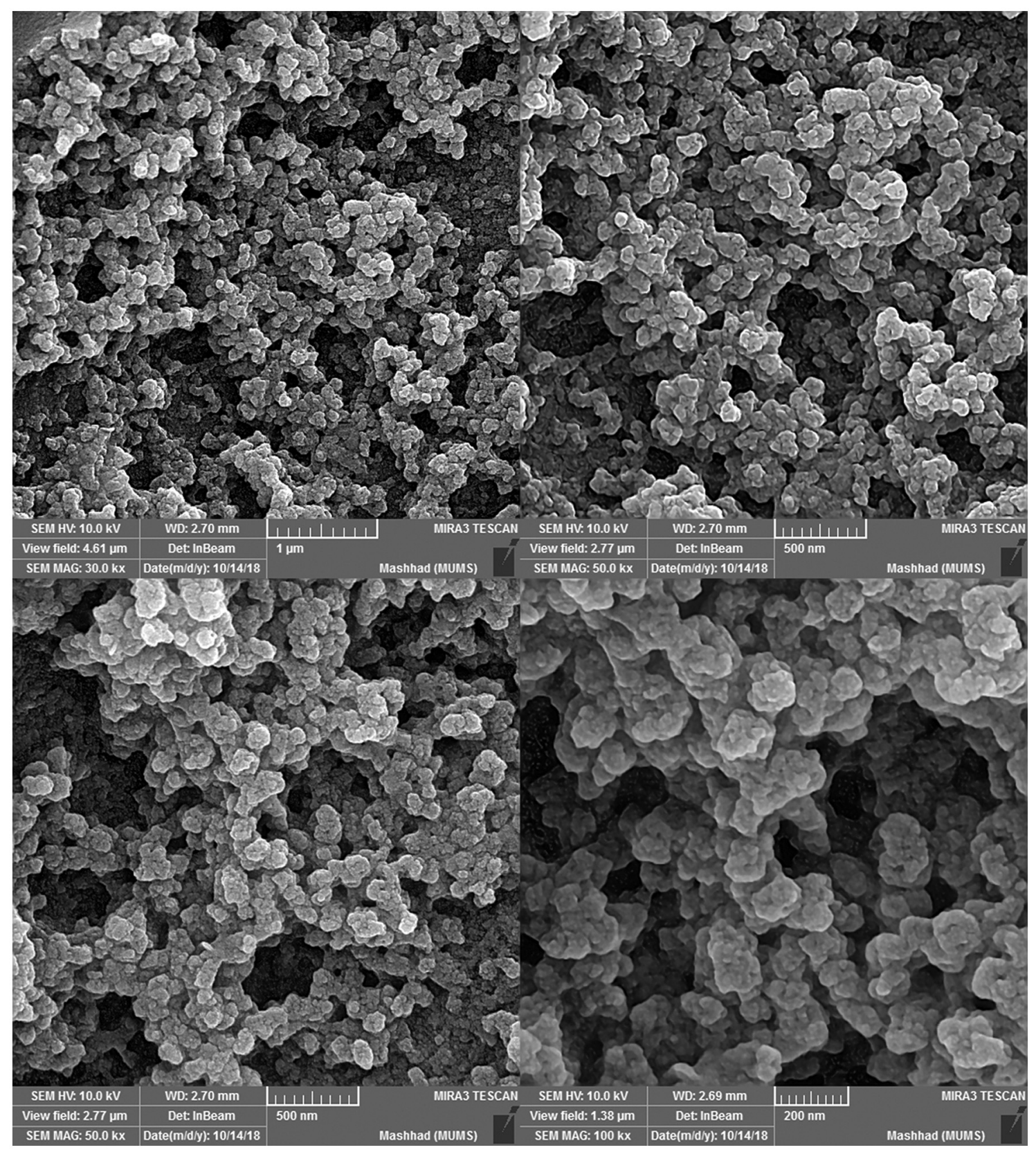

Figure 10: $\mathrm{SEM}$ images of $\mathrm{SrTiO}_{3}$ nanoparticle synthesis autocombustion.

\subsection{Photocatalytic properties}

The photocatalytic properties of the $\mathrm{SrFe}_{12} \mathrm{O}_{19}-\mathrm{SrTiO}_{3}$ nanocomposite were checked via degradation of four azo dyes in the form of an aqueous solution, under irradiation of UV light (Hedayati et al., 2016; Kiani et al., 2019; Nabiyouni and Ghanbari, 2018; Sabet et al., 2014; SalavatiNiasari et al., 2009). The UV-Vis absorption spectra of (a) acid black, (b) acid brown, (c) methyl red, and (d) methyl orange azo dyes in the presence of $\mathrm{SrFe}_{12} \mathrm{O}_{19}-\mathrm{SrTiO}_{3}$ nanocomposite were shown in Figure 19.
In order to carry out this photocatalytic procedure, $0.5 \mathrm{~g}$ of synthesized $\mathrm{SrFe}_{12} \mathrm{O}_{19}-\mathrm{SrTiO}_{3}$ nanocomposite were placed each in $50 \mathrm{~mL}$ solutions of 4 above colored dyes under microwave conditions and laboratory UV light. With passing time, more and more dyes concentration were adsorbed via the nanoparticles catalyst until the absorption peaks $\left(k_{\max }\right)$ of acid black, acid brown, methyl red and methyl orange decreased and vanished approximately after $60 \mathrm{~min}$. As shown in Figure 20, black acid in $30 \mathrm{~min}$ about $95 \%$, brown acid in $40 \mathrm{~min}$ about 97\%, methyl red in $40 \mathrm{~min}$ around $98 \%$ and methyl 


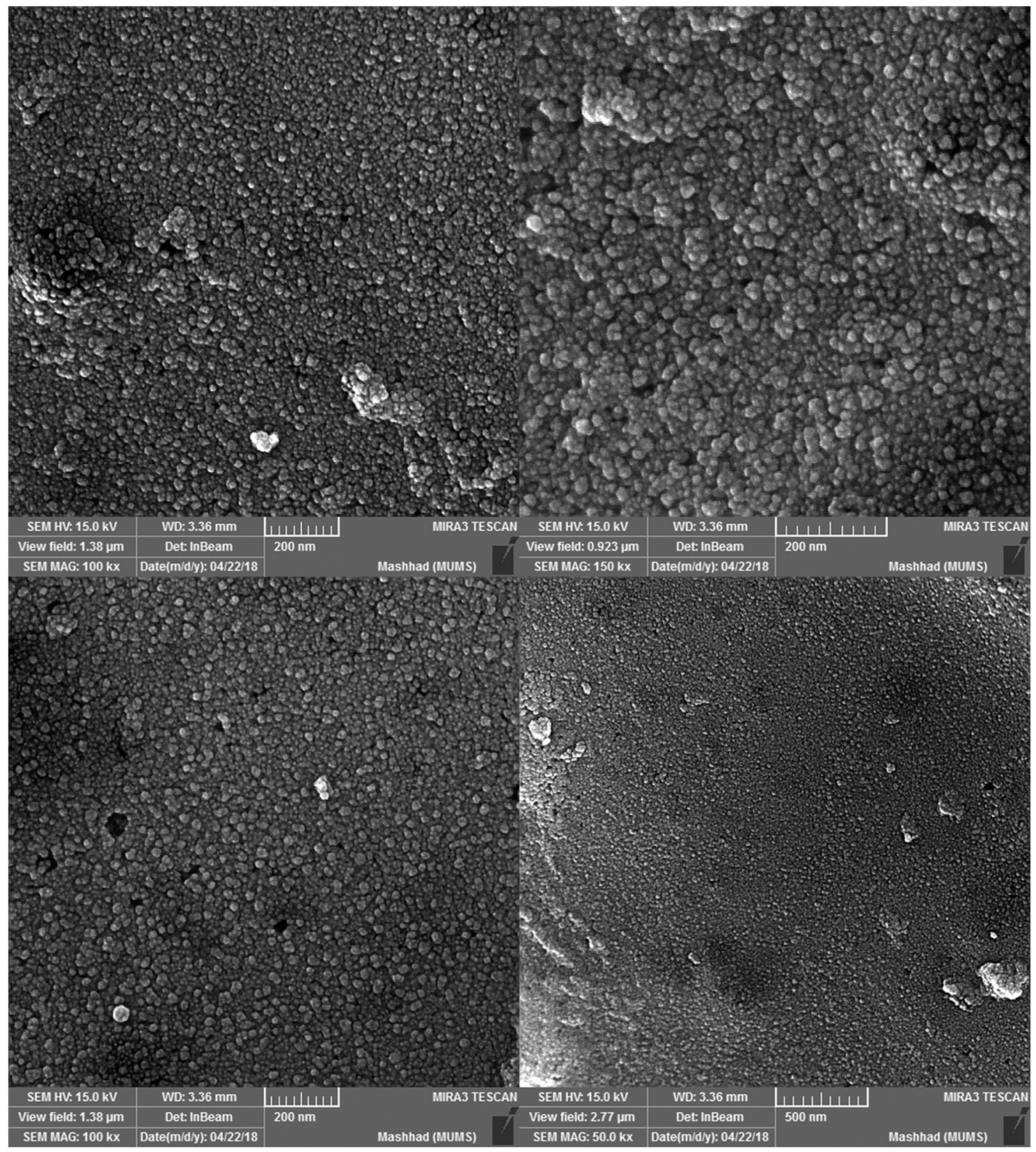

Figure 11: $\mathrm{SEM}$ images of $\mathrm{SrTiO}_{3}$ nanoparticle synthesis autocombustion that calcinate at $500^{\circ} \mathrm{C}$.

orange in $60 \mathrm{~min}$ about $95 \%$ were degraded. These results indicate good photocatalytic strength of the synthesized nanocomposite. Finally, the magnetic nanocomposite powder can also be extracted by the magnet and removed from the solution. Then, by centrifugation and rinsing it with deionized double distilled water, it is ready for reuse in the next dye. The mechanism of photo-degradation of toxic azo-dyes under ultraviolet irradiation photocatalytic nanocomposite $\mathrm{SrFe}_{12} \mathrm{O}_{19}-\mathrm{SrTiO}_{3}$ with an indirect bandgap about $3.2 \mathrm{eV}$ is depicted in Figure 21. As it was shown before, organic dyes decompose to $\mathrm{CO}_{2}, \mathrm{H}_{2} \mathrm{O}$, and other less toxic or nontoxic remaining materials (Gillani et al., 2020;
Hasegawa et al., 2000; Piskunov et al., 2004). Tabel 2 shows some related published works about photocatalytic properties.

\section{Conclusion}

In this study, $\mathrm{SrFe}_{12} \mathrm{O}_{19}-\mathrm{SrTiO}_{3}$ nanocomposite was prepared using a green synthesis by auto-combustion sol-gel method using lemon juice extracts. The XRD pattern of the $\mathrm{SrFe}_{12} \mathrm{O}_{19}$ and $\mathrm{SrTiO}_{3}$ nanoparticles and 


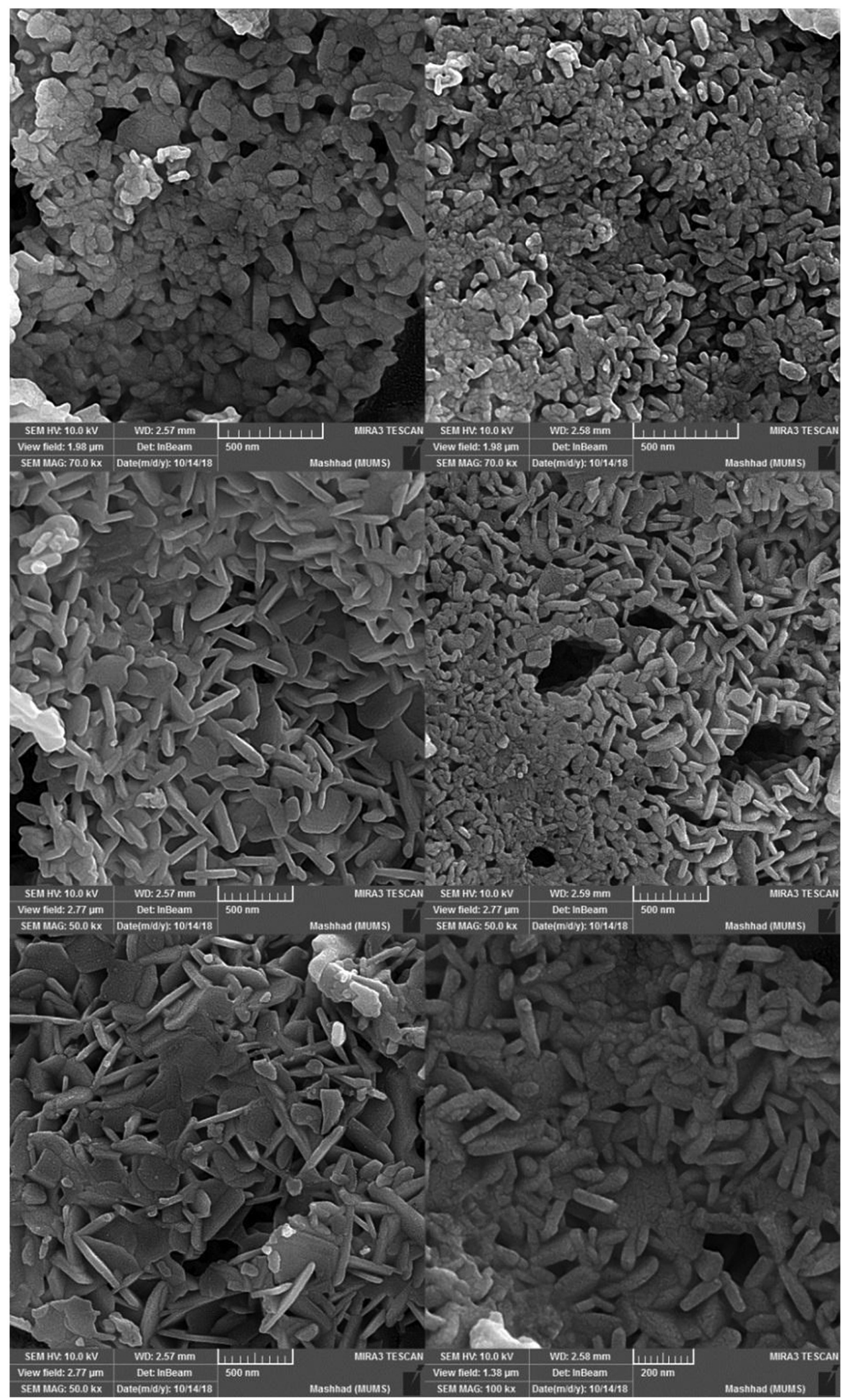

Figure 12: $\mathrm{SEM}$ images of nanocomposite $\mathrm{SrFe}_{12} \mathrm{O}_{19}-\mathrm{SrTiO}_{3}$ synthesis autocombustion. 


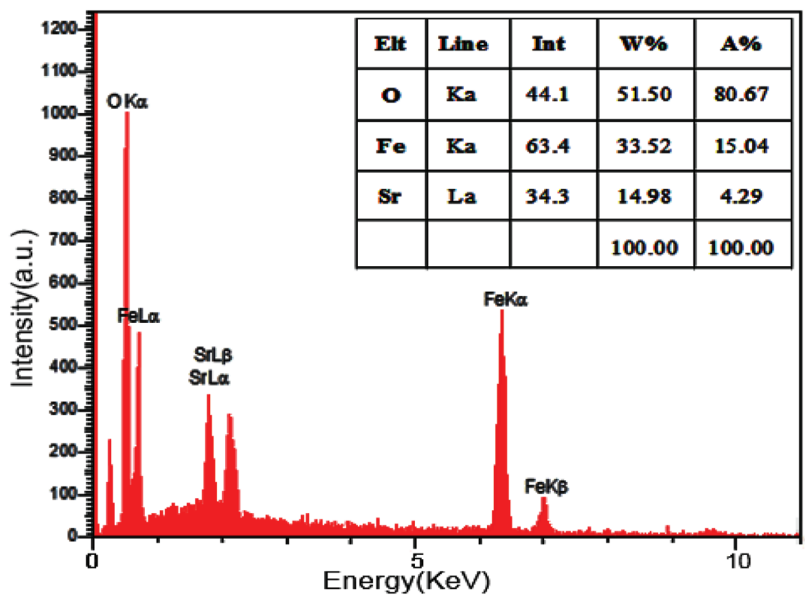

Figure 13: $\mathrm{EDX}$ of $\mathrm{SrFe}_{12} \mathrm{O}_{19}$ calcinated at $850^{\circ} \mathrm{C}$.

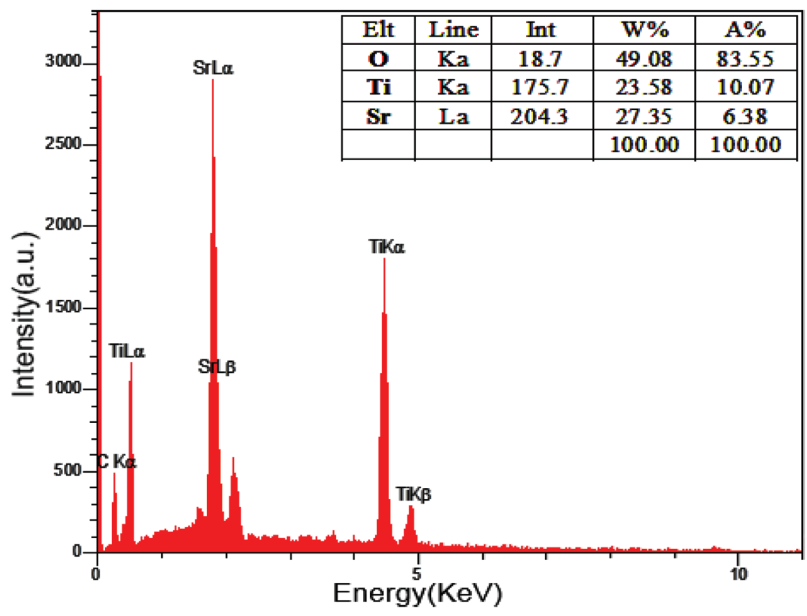

Figure 14: $\mathrm{EDX}$ of $\mathrm{SrTiO}_{3}$ calcinated at $500^{\circ} \mathrm{C}$.

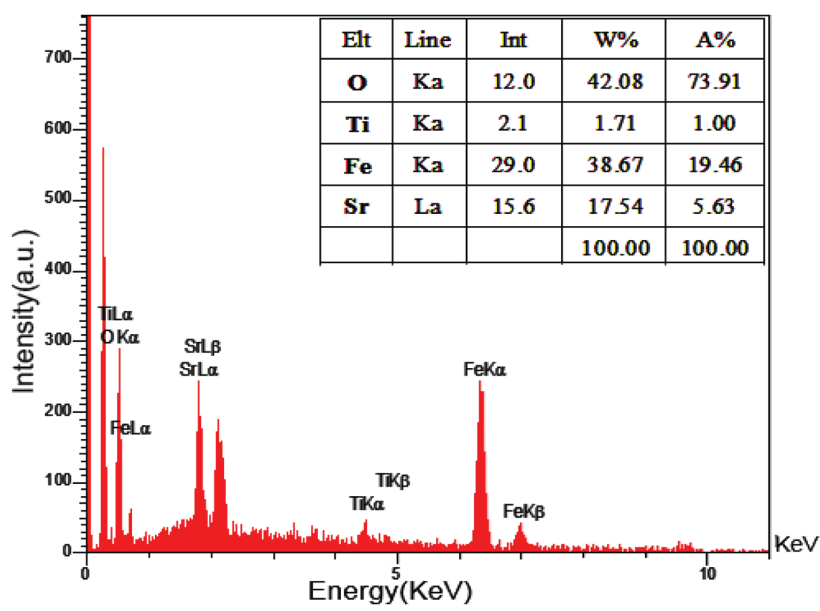

Figure 15: $\mathrm{EDX}$ of nanocomposite $\mathrm{SrFe}_{12} \mathrm{O}_{19}-\mathrm{SrTiO}_{3}$.

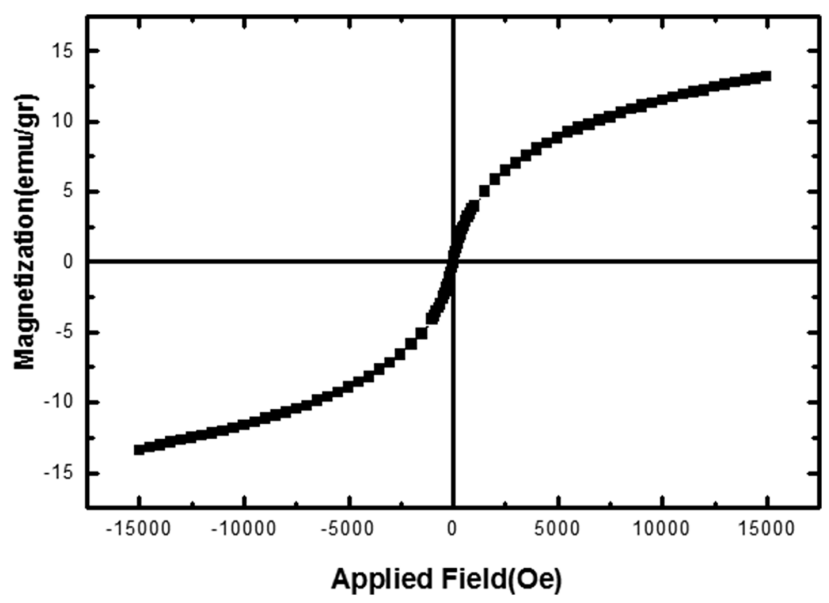

Figure 16: VSM of $\mathrm{SrFe}_{12} \mathrm{O}_{19}$ at room temperature.

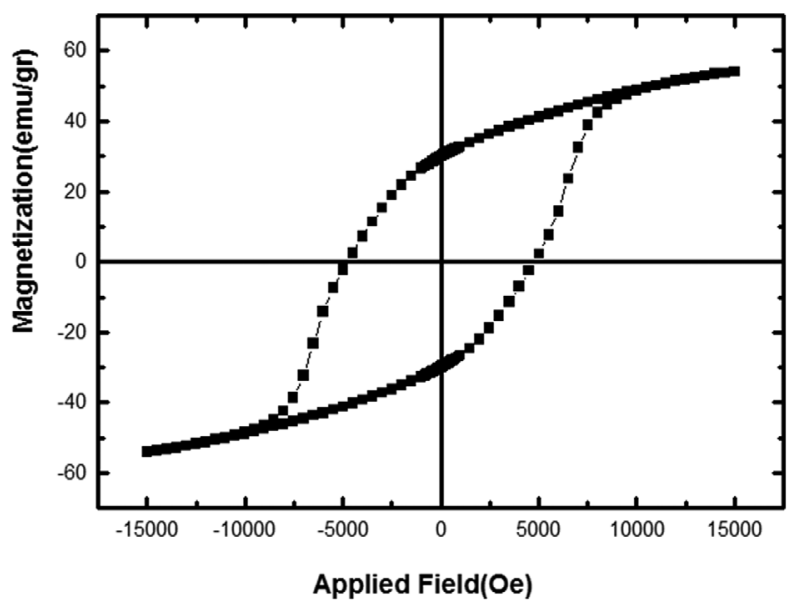

Figure 17: $\mathrm{VSM}$ of nanoparticle $\mathrm{SrFe}_{12} \mathrm{O}_{19}$ calcinated at $850^{\circ} \mathrm{C}$.

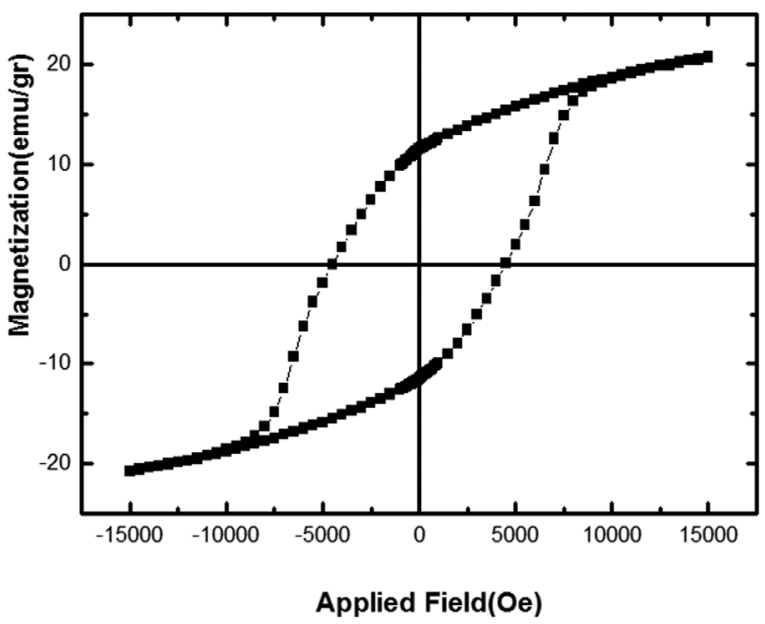

Figure 18: VSM of nanocomposite $\mathrm{SrFe}_{12} \mathrm{O}_{19}-\mathrm{SrTiO}_{3}$. 


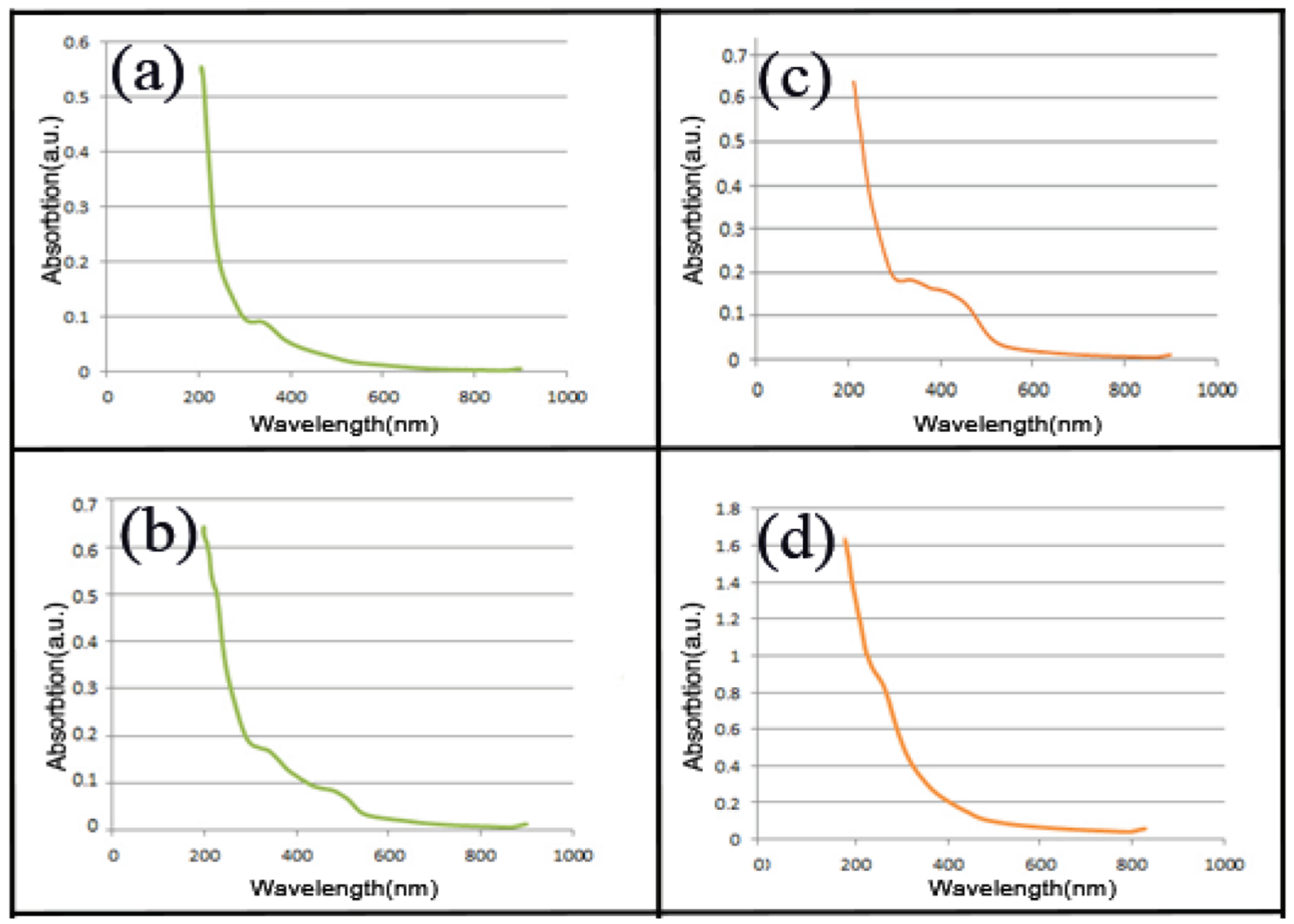

Figure 19: UV-Vis absorption spectra of (a) acid black, (b) acid brown, (c) methyl red, and (d) methyl orange in the presence of nanocomposite $\mathrm{SrFe}_{12} \mathrm{O}_{19}-\mathrm{SrTiO}_{3}$ photocatalyst.

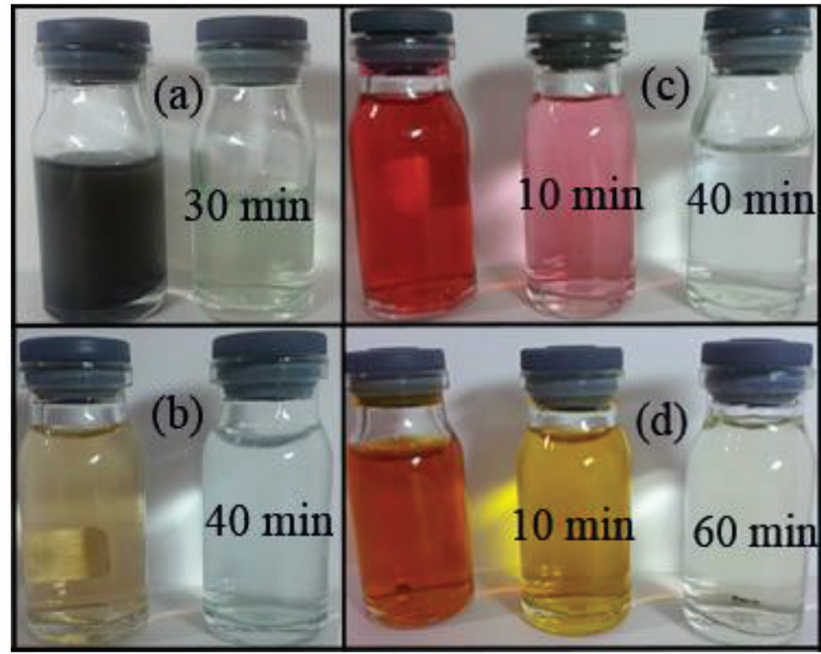

Figure 20: Photo-degradation of (a) acid black, (b) acid brown, (c) methyl red, and (d) methyl orange in the presence of nanocomposite $\mathrm{SrFe}_{12} \mathrm{O}_{19}-\mathrm{SrTiO}_{3}$

$\mathrm{SrFe}_{12} \mathrm{O}_{19}-\mathrm{SrTiO}_{3}$ nanocomposite have shown a pattern of pure hexaferrite strontium and perovskite strontium phase. The nanocrystalline size and the strain of the network of all particles have been calculated using the

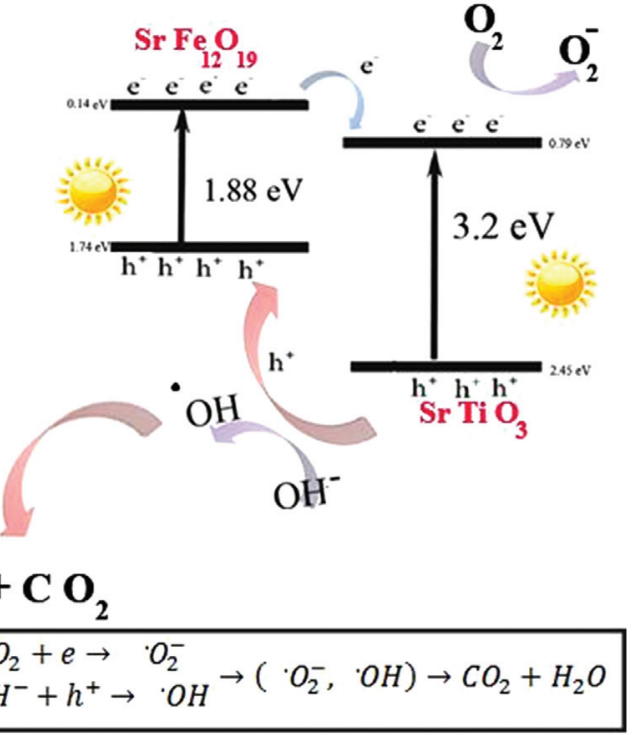

Figure 21: Photo-catalyst mechanism of $\mathrm{SrFe}_{12} \mathrm{O}_{19}-\mathrm{SrTiO}_{3}$ in the case of degradation of toxic dye.

Debye-Scherrer and Williamson-Hall method. The FTIR spectrum of the $\mathrm{SrFe}_{12} \mathrm{O}_{19}$ nanoparticles shows the $\mathrm{Fe}-\mathrm{O}$ and $\mathrm{Sr}-\mathrm{O}$ band peaks. FTIR spectrum of $\mathrm{SrTiO}_{3}$ nanoparticles indicates the band of $\mathrm{Ti}-\mathrm{O}$ and $\mathrm{Sr}-\mathrm{O}$ peaks. Also, in the 
Table 2: Related published works about photocatalytic properties.

\begin{tabular}{|c|c|c|c|c|c|c|}
\hline & Nonoparticles & Methods & $\begin{array}{c}\text { Average crystal- } \\
\text { line size }\end{array}$ & \multicolumn{3}{|c|}{ Photo activity of nano-photo-catalyst } \\
\hline \multirow{4}{*}{ Our results } & \multirow{4}{*}{$\begin{array}{l}\mathrm{SrFe}_{12} \mathrm{O}_{19}- \\
\mathrm{SrTiO}_{3}\end{array}$} & \multirow{4}{*}{ Auto-combustion } & \multirow{4}{*}{$50 \mathrm{~nm}$} & acid black & $30 \mathrm{~min}$ & $95 \%$ \\
\hline & & & & acid brown & $40 \mathrm{~min}$ & $97 \%$ \\
\hline & & & & methyl red & $40 \mathrm{~min}$ & $98 \%$ \\
\hline & & & & methyl orange & $60 \mathrm{~min}$ & $95 \%$ \\
\hline \multirow{3}{*}{$\begin{array}{l}\text { (Hedayat et al., } \\
\text { 2016) }\end{array}$} & \multirow{3}{*}{$\mathrm{CoFe}_{2} \mathrm{O}_{4}-\mathrm{CdS}$} & \multirow{3}{*}{ precipitation } & \multirow{3}{*}{$90 \mathrm{~nm}$} & acid black & \multicolumn{2}{|c|}{$80 \mathrm{~min}$} \\
\hline & & & & acid brown & \multicolumn{2}{|c|}{$100 \mathrm{~min}$} \\
\hline & & & & acid blue & \multicolumn{2}{|c|}{$120 \mathrm{~min}$} \\
\hline \multirow{2}{*}{$\begin{array}{l}\text { (Mehdizadeh et } \\
\text { al., 2020) }\end{array}$} & \multirow{2}{*}{$\mathrm{LaFeO}_{3}$} & \multirow{2}{*}{ sonochemical } & \multirow{2}{*}{$67 \mathrm{~nm}$} & degrades erythrosine under visible light & $90 \mathrm{~min}$ & $53 \%$ \\
\hline & & & & degrades of erythrosine under UV light & $90 \mathrm{~min}$ & $93.5 \%$ \\
\hline \multirow{3}{*}{$\begin{array}{l}\text { (Monsef et al., } \\
2020 \text { ) }\end{array}$} & \multirow{3}{*}{$\mathrm{PrVO}_{4}$} & \multirow{3}{*}{ sonochemical } & \multirow{3}{*}{$25 \mathrm{~nm}$} & destruction of eriochrome black $\mathrm{T}$ & \multicolumn{2}{|c|}{$89.61 \%$} \\
\hline & & & & decoloration of erythrosine & \multicolumn{2}{|c|}{$27.92 \%$} \\
\hline & & & & methyl violet & \multicolumn{2}{|c|}{$8.48 \%$} \\
\hline $\begin{array}{l}\text { (Ahmadi Golse- } \\
\text { fidi et al., 2016) }\end{array}$ & $\mathrm{Fe}_{2} \mathrm{O}_{3}-\mathrm{TiO}_{2}$ & sonochemical & $60 \mathrm{~nm}$ & methylene blue & \multicolumn{2}{|c|}{$81 \%$} \\
\hline
\end{tabular}

FTIR spectrum of the $\mathrm{SrFe}_{12} \mathrm{O}_{19}-\mathrm{SrTiO}_{3}$ nanocomposite all peaks of $\mathrm{SrFe}_{12} \mathrm{O}_{19}$ and $\mathrm{SrTiO}_{3}$ nanoparticles were observed. SEM images of $\mathrm{SrFe}_{12} \mathrm{O}_{19}$ and $\mathrm{SrTiO}_{3}$ nanoparticles have shown calcination caused reduce agglomeration of particles. Also, all images have an average size under $100 \mathrm{~nm}$ and the grain sizes are well estimated with crystallite sizes calculated by XRD patterns. The EDX analysis of nanoparticles and nanocomposites show particles without impurities and with a good estimate, stoichiometric amount of elements in nanoparticles. The hysteresis loop of $\mathrm{SrFe}_{12} \mathrm{O}_{19}$ shows that nanoparticles without calcination is superparamagnetic and calcined at $850^{\circ} \mathrm{C}$ is ferromagnetic. Also, hysteresis loops of $\mathrm{SrFe}_{12} \mathrm{O}_{19}$ confirmed by calcined as both magnetization and coercivity were increased. Magnetic studies of $\mathrm{SrFe}_{12} \mathrm{O}_{19}-\mathrm{SrTiO}_{3}$ nanocomposite indicate magnetization and coercivity have decreased in the composite because of the $\mathrm{SrTiO}_{3}$ shell. The photocatalytic properties of the $\mathrm{SrFe}_{12} \mathrm{O}_{19}-\mathrm{SrTiO}_{3}$ nanocomposite were investigated under irradiation of UV light. $\mathrm{SrFe}_{12} \mathrm{O}_{19}-\mathrm{SrTiO}_{3}$ nanocomposite degraded more than $90 \%$ of black acid, brown acid, methyl red, and methyl orange in less than $60 \mathrm{~min}$. While the simplicity of this photocatalyst synthesis is one of its possible advantages, it is time-consuming that this can be its disadvantage.The results denoted that $\mathrm{SrFe}_{12} \mathrm{O}_{19}-$ $\mathrm{SrTiO}_{3}$ nanocomposite has the potential to be applied for improving and removing organic and toxic water pollutants.

\section{References}

Ahmadian-Fard-Fini S., Ghanbari D., Amiri O., Salavati-Niasari, M., Electro-spinning of cellulose acetate nanofibers/Fe/carbon dot as photoluminescence sensor for mercury (II) and lead (II) ions. Carbohyd. Polym., 2020, 229, 115428.

Ahmadian-Fard-Fini S., Salavati-Niasari M., Ghanbari D., Hydrothermal green synthesis of magnetic $\mathrm{Fe}_{3} \mathrm{O}_{4}$-carbon dots by lemon and grape fruit extracts and as a photoluminescence sensor for detecting of $E$. coli bacteria. Spectrochim. Acta A, 2018, 203, 481-493.

Ahmadi Golsefidi M., Abbasi F., Abrodi M., Abbasi Z., Yazarlou F., Synthesis, characterization and photocatalytic activity of Fe203-TiO2 nanoparticles and nanocomposites. J. Nanostruct., 2016, 6(1), 64-69.

Almessiere M.A., Slimani Y., Güngüneş H., El Sayed H.S., Baykal A., AC susceptibility and Mossbauer study of $\mathrm{Ce}^{3+}$ ion substituted $\mathrm{SrFe}_{12} \mathrm{O}_{19}$ nanohexaferrites. Ceram. Int., 2018, 44(9), 10470-10477.

Ariaee S., Mehdipour M., Moradnia M., Spectroscopy of peaks at microwave range for nanostructure $\mathrm{SrFe}_{12} \mathrm{O}_{19}$ and $\mathrm{NiFe}_{2} \mathrm{O}_{4}$ ferrite particles. J. Magn. Magn. Mater., 2017, 429, 348-352.

Auwal I. A., Erdemi H., Sözeri H., Güngüneş H., Baykal A., Magnetic and dielectric properties of $\mathrm{Bi}^{3+}$ substituted $\mathrm{SrFe}_{12} \mathrm{O}_{19}$ hexaferrite. J. Magn. Magn. Mater., 2016, 412, 69-82.

Davar F., Salavati-Niasari M., Mir N., Saberyan K., Monemzadeh M., Ahmadi E., Thermal decomposition route for synthesis of $\mathrm{Mn}_{3} \mathrm{O}_{4}$ nanoparticles in presence of a novel precursor. Polyhedron, 2010, 29(7), 1747-1753.

Deganello F., Marcì G., Deganello G., Citrate-nitrate auto-combustion synthesis of perovskite-type nanopowders: A systematic approach. J. Eur. Ceram. Soc., 2009, 29(3), 439-450. 
Dong S., Feng J., Fan M., Pi Y., Hu L., Han X., et al., Recent developments in heterogeneous photocatalytic water treatment using visible light-responsive photocatalysts: a review. RSC Adv., 2015, 19, 14610-14630.

Eskandari N., Nabiyouni G., Masoumi S., Ghanbari D., Preparation of a new magnetic and photo-catalyst $\mathrm{CoFe}_{2} \mathrm{O}_{4}-\mathrm{SrTiO}_{3}$ perovskite nanocomposite for photo-degradation of toxic dyes under short time visible irradiation. Compos. Part B-Eng., 2019, 176, 107343.

Fang J., Wang J., Gan L.M., Ng S.C., Ding J., Liu X., Fine Strontium Ferrite Powders from an Ethanol-Based Microemulsion. J. Am. Ceram. Soc., 2000, 83(5), 1049-1055.

Garcıa-Cerda L.A., Rodrıguez-Fernandez O.S., Resendiz-Hernandez P.J., Study of $\mathrm{SrFe}_{12} \mathrm{O}_{19}$ synthesized by the sol-gel method. J. Alloy. Compd., 2004, 369(1-2), 182-184.

Gaya U.I., Abdullah A.H., Heterogeneous photocatalytic degradation of organic contaminants over titanium dioxide: a review of fundamentals, progress and problems. J. Photoch. Photobio. C, 2008, 9 (1), 1-12.

Gillani S.S., Riaz A., Rizwan M., Shakil M., Rafique M., Murtaza G., et al., First-principles investigation of structural, electronic, optical and thermal properties of Zinc doped $\mathrm{SrTiO}_{3}$. Optik, 2020, 201, 163481.

Hasegawa T., Shirai M., Tanaka K., Localizing nature of photo-excited states in $\mathrm{SrTiO}_{3}$. J. Lumin., 2000, 87, 1217-1219.

Hedayati K., Azarakhsh S., Saffari J., Ghanbari D., Photo catalyst $\mathrm{CoFe}_{2} \mathrm{O}_{4}-\mathrm{CdS}$ nanocomposites for degradationof toxic dyes: investigation of coercivity and magnetization. J. Mater. Sci.-Mater. El., 2016, 27, 8758-8770.

Hedayati K., Behesht-Ara Z., Ghanbari D., Preparation and characterization of various morphologies of $\mathrm{SrFe}_{12} \mathrm{O}_{19}$ nano-structures: investigation of magnetization and coercivity. J. Mater. Sci.-Mater. El., 2017a, 28(1), 1-9.

Hedayati K., Kord M., Goodarzi M., Ghanbari D., Gharigh S., Photo-catalyst and magnetic nanocomposites: hydrothermal preparation of core-shell $\mathrm{Fe}_{3} \mathrm{O}_{4} @ \mathrm{PbS}$ for photo-degradation of toxic dyes. J. Mater. Sci.-Mater. El., 2017b, 28, 1577-1589.

Hua Z., Cao Z., Deng Y., Jiang Y., Yang S., Sol-gel autocombustion synthesis of Co-Ni alloy powder. Mater. Chem. Phys., 2011, 126(3), 542-545.

Jacobo S.E., Bercoff P.G., Coercivity enhancement of hexagonal ferrites. Sol. State Phenom., 2013, 202, 113-125.

Khorsand Zak A., Abd. Majid W.H., Abrishami M.E., Yousefi R., $\mathrm{X}$-ray analysis of $\mathrm{ZnO}$ nanoparticles by Williamsone-Hall and sizeestrain plot methods. Solid State Sci., 2011, 13(1), 251-256.

Kiani A., Nabiyouni G., Masoumi S., Ghanbari D., A novel magnetic $\mathrm{MgFe}_{2} \mathrm{O}_{4}-\mathrm{MgTiO}_{3}$ perovskite nanocomposite: Rapid photodegradation of toxic dyes under visible irradiation. Compos. Part B-Eng., 2019, 175, 107080.

Lahijani B., Hedayati K., Goodarzi M., Magnetic $\mathrm{PbFe}_{12} \mathrm{O}_{19}-\mathrm{TiO}_{2}$ nanocomposites and their photocatalytic performance in the removal of toxic pollutants. Main Group Met. Chem., 2018, 41(3-4), 53-62.

Madhavi V., Prasad T.N.V.K.V., Reddy A.V.B., Reddy B.R., Madhavi G., Application of phytogenic zerovalent iron nanoparticles in the adsorption of hexavalent chromium Spectrochim. Acta A-M., 2013, 116, 17-25.

Mali A., Ataie A., Influence of the metal nitrates to citric acid molar ratio on the combustion process and phase constitution of barium hexaferrite particles prepared by sol-gel combustion method. Ceram. Int., 2004, 30(7), 1979-1983.
Mehdizadeh P., Amiri O., Rashki S., Salavati-Niasari M., Salimian M., Foong L.K., Effective removal of organic pollution by using sonochemical prepared $\mathrm{LaFeO}_{3}$ perovskite under visible light. Ultrason. Sonochem., 2020, 61, 104848.

Meng X., Xu S., Zhou J., Tang Q., Monodisperse hexagonal $\mathrm{SrFe}_{12} \mathrm{O}_{19}$ nanoflake with enchanced magnetic properties. Ceram. Int., 2016, 42(5), 6025-6032.

Mir N., Salavati-Niasari M., Davar F., Preparation of ZnO nanoflowers and $\mathrm{Zn}$ glycerolate nanoplates using inorganic precursors via a convenient rout and application in dye sensitized solar cells. Chem. Eng. J., 2012, 181, 779-789.

Mohandes F., Davar F., Salavati-Niasari M., Magnesium oxide nanocrystals via thermal decomposition of magnesium oxalate. J. Physi. Chem. Solids, 2010, 71(12), 1623-1628.

Mohandes F., Salavati-Niasari M., Freeze-drying synthesis, characterization and in vitro bioactivity of chitosan/graphene oxide/ hydroxyapatite nanocomposite. RDC Adv., 2014, 4(49), 25993-26001.

Monsef R., Ghiyasiyan-Arani M., Amiri O., Salavati-Niasari M., Sonochemical synthesis, characterization and application of $\mathrm{PrVO}_{4}$ nanostructures as an effective photocatalyst for discoloration of organic dye contaminants in wastewater. Ultrason. Sonochem., 2020, 61, 104822.

Mousavi-Kamazani M., Zarghami Z., Salavati-Niasari M., Facile and novel chemical synthesis characterization and formation mechanism of copper sulfide $\left(\mathrm{Cu}_{2} \mathrm{~S}, \mathrm{Cu}_{2} \mathrm{~S} / \mathrm{CuS}, \mathrm{CuS}\right)$ nanostructures for increasing the efficiency of solar cells. J. Phys. Chem. C, 2016, 120(4), 2096-2108.

Nabiyouni G., Ghanbari D., Simple preparation of magnetic, antibacterial and photo-catalyst $\mathrm{NiFe}_{2} \mathrm{O}_{4} @ \mathrm{TiO}_{2} / \mathrm{Pt}$ nanocomposites. J. Nanostruct., 2018, 8(4), 408-416.

Nadagouda M.N., Castle A.B., Murdock R.C., Hussain S.M., Varma R.S., In vitro biocompatibility of nanoscale zerovalent iron particles (NZVI) synthesized using tea polyphenols. Green Chem., 2010, 12(1), 114-122.

Palomino R.L., Miró A.B., Tenorio F.N., De Jesús F.S., Escobedo C.C., Ammar S., Sonochemical assisted synthesis of $\mathrm{SrFe}_{12} \mathrm{O}_{19}$ nanoparticles. Ultrason. Sonochem., 2016, 29, 470-475.

Piskunov S., Heifets E., Eglitis R.I., Borstel G., Bulk properties and electronic structure of $\mathrm{SrTiO}_{3}, \mathrm{BaTiO}_{3}, \mathrm{PbTiO}_{3}$ perovskites: an ab initio HF/DFT study. Comp. Mater. Sci., 2004, 29(2), 165-178.

Sabet M., Salavati-Niasari M., Amiri O., Using different chemical methods for deposition of $\mathrm{CdS}$ on $\mathrm{TiO} 2$ surface and investigation of their influences on the dye-sensitized solar cell performance. Electrochim. Acta, 2014, 117, 504-520.

Safardoust-Hojaghan H., Salavati-Niasari M., Degradation of methylene blue as a pollutant with $\mathrm{N}$-doped graphene quantum dot/titanium dioxide nanocomposite. J. Clean. Prod., 2017, 148, 31-36.

Salavati-Niasari M., Ship-in-a-bottle synthesis, characterization and catalytic oxidation of styrene by host (nanopores of zeolite-Y)/ guest ([bis (2-hydroxyanil) acetylacetonato manganese (III)]) nanocomposite materials (HGNM). Micropor. Mesopor. Mat., 2006, 95(1-3), 248-256.

Salavati-Niasari M., Amiri A., Synthesis and characterization of alumina-supported Mn (II), Co (II), Ni (II) and CU (II) complexes of bis (salicylaldiminato) hydrazone as catalysts for oxidation of cyclohexene with tert-buthylhydroperoxide. Appl. Catal. A-Gen., 2005, 290, 1-2, 46-53. 
Salavati-Niasari M., Davar F., In situ one-pot template synthesis (IOPTS) and characterization of copper (II) complexes of 14-membered hexaaza macrocyclic ligand "3, 10-dialkyldibenzo-1, 3, 5, 8, 10, 12-hexaazacyclotetradecane. Inorg. Chem. Commun., 2006, 9(2), 175-179.

Salavati-Niasari M., Davar F., Loghman-Estarki M.R., Controllable synthesis of thioglycolic acid capped $\mathrm{ZnS}(\mathrm{Pn}) 0.5$ nanotubes via simple aqueous solution route at low temperatures and conversion to wurtzite $\mathrm{ZnS}$ nanorods via thermal decompose of precursor. J. Alloy. Compd., 2010, 494(1-2), 199-204.

Salavati-Niasari M., Farhadi-Khouzani M., Davar F., Bright blue pigment $\mathrm{CoAl}_{2} \mathrm{O}_{4}$ nanocrystals prepared by modified sol-gel method. J. Sol-Gel Sci. Tech., 2009, 52(3), 321-327.

Salavati-Niasari M., Nanodimensional microreactor-encapsulation of 18-membered decaaza macrocycle copper (II) complexes. Chem. Lett., 2005a, 34(2), 244-245.

Salavati-Niasari M., Nanoscale microreactor-encapsulation 14-membered nickel (II) hexamethyl tetraaza: synthesis, characterization and catalytic activity. J. Mol. Catal. A-Chem., 2005b, 229(1-2), 159-164.

Salavati-Niasari M., Zeolite-encapsulation copper (II) complexes with 14-membered hexaaza macrocycles: synthesis, characterization and catalytic activity. J. Mol. Catal. A-Chem., 2004, 217(1-2), 87-92.

Shabanian M., Basaki N., Khonakdar H.A., Jafari S.H., Hedayati K., Wagenknecht U., Novel nanocomposites consisting of a semi-crystalline polyamide and Mg-Al LDH: Morphology, thermal properties and flame retardancy. Appl. Clay Sci., 2014, 90, 101-108.

Thornton G., Tofield B.C., Williams D.E., Spin state equilibria and the semiconductor to metal transition of $\mathrm{LaCoO}_{3}$. Solid State Commun., 1982, 44(8), 1213-1216.
Valenzuela R., Novel applications of ferrites. Phys. Res. Int., 2012, 44(38).

Wang Y., Li Q., Zhang C., Li B., Effect of Fe/Sr mole ratios on the formation and magnetic properties of $\mathrm{SrFe}_{12} \mathrm{O}_{19}$ microtubules prepared by sol-gel method. J. Magn. Magn. Mater., 2009a, 321(19), 3368-3372.

Wang Y., Li Q., Zhang C., Jing H., Preparation and magnetic properties of different morphology nano- $\mathrm{SrFe}_{12} \mathrm{O}_{19}$ particles prepared by sol-gel method. J. Alloy. Compd., 2009b, 467(1-2), 284-287

Wohlfarth E.P., Buschow K.H.J., Ferromagnetic Materials: A Handbook on the properties of Magnetically Ordered Substances(Chapter5). North-Holland, 1982, 305-391.

Xia A., Zuo C., Chen L., Jin C., Lv Y., Hexagonal $\mathrm{SrFe}_{12} \mathrm{O}_{19}$ ferrites: hydrothermal synthesis and their sintering properties. J. Magn. Magn. Mater., 2013, 332, 186-191.

Yang X., Li Q., Zhao J., Li B., Wang Y., Preparation and magnetic properties of controllable-morphologies nano- $\mathrm{SrFe}_{12} \mathrm{O}_{19}$ particles prepared by sol-gel self-propagation synthesis. J. Alloy. Compd., 2009, 475(1-2), 312-315.

Yousefi M., Gholamian F., Ghanbari D., Salavati-Niasari M., Polymeric nanocomposite materials: preparation and characterization of star-shaped $\mathrm{PbS}$ nanocrystals and their influence on the thermal stability of acrylonitrile-butadiene-styrene (ABS) copolymer. Polyhedron, 2011, 30(6), 1055-1060.

Zhu F., Ma S., Liu T., Deng X., Green synthesis of nano zero-valent iron/Cu by green tea to remove hexavalent chromium from groundwater. J. Clean. Prod., 2018, 174, 184-190.

Zinatloo-Ajabshir S., Salavati-Niasari M., Nanocrystalline $\operatorname{Pr}_{6} \mathrm{O}_{11}$ : synthesis, characterization, optical and photocatalytic properties. New J. Chem., 2015, 39(5), 3948-3955. 